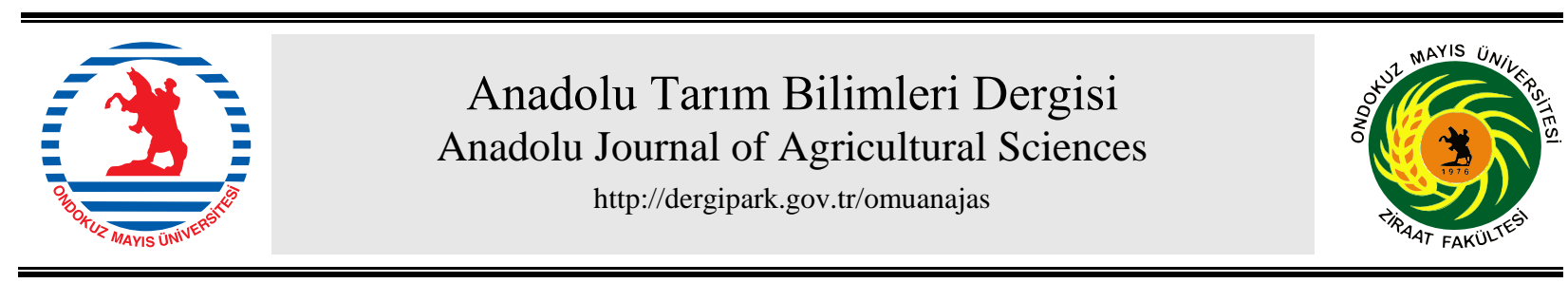

Araştırma/Research

\title{
Yarı kurak bölgelerde sentetik açıklıklı radar (mikrodalga) görüntüleri ile toprak neminin tahmini
}

\author{
Tülay Tunçay \\ Toprak Gübre ve Su Kaynakları Merkez Araştırma Enstitüsü Müdürlügü, Ankara, Türkiye
}

*Sorumlu yazar/corresponding author: tulaytuncay@gmail.com

Geliş/Received 10/04/2019 Kabul/Accepted 07/01/2020

\begin{abstract}
ÖZET
Toprak neminin konumsal ve zamansal olarak dağılımı, kurak ve yarı kurak bölgelerde kuraklık izlemesi, ürün sulama planlaması, ürün tahmini gibi havza seviyesindeki tarımsal uygulamalarda anahtar bir parametredir. Ayrıca, radar uydu görüntüleri çeșitli bölgeler iç̣in toprak ve bitki örtüsü dağılımının mekânsal ve zamansal olarak ortaya konulmasını sağlamak için kullanılmaktadır. Aktif mikrodalga sensör sistemleri kullanarak yüzey toprağı neminin tahmini araştırmacılar, koruma planlamacıları ve doğal kaynakların sürdürülebilir kullanımını izleyen karar vericiler için yararlı bilgilerden biridir. Bu çalışma, yarı kurak iklime sahip Altınova Tarım İşletmesi arazisinde seçilen altmış dört kilometrekarelik test alanı topraklarında yürütülmüștür. Dört farklı zamanda elde edilen Sentetik Açıklıklı Radar (SAR) görüntülerinin gerisaçılım değerleri (Radarsat-2) ve yüzey toprağı nemi arasındaki ilişki belirlenmeye çalışılmıştır. Bu amaçla, Altınova Tarım İşletmesine ait dört SAR görüntüsü (4 tane Radarsat-2 görüntüsü) kullanılmıştır. Eş zamanlı olarak, 730 farklı noktada $250 \mathrm{~m}$ aralıklarla yüzey toprak örnekleri $0-20 \mathrm{~cm}$ 'den alınmış ve çalışma alanı boyunca gravimetrik yöntem kullanılarak yüzey toprağının nemi belirlenmiștir. Her örnekleme periyodu için yüzey toprağı nem dağılım haritaları ordinary kriging kullanılarak üretilmiştir. Toprak nem dağılım haritalarına göre Ağustos verileri, çalışma alanı boyunca diğer örnekleme dönemlerine kıyasla yüzey toprağı neminde en fazla değişiklikleri göstermiştir. Bu nedenle çalışma alanı boyunca gerisaçılma (Ağustos 2012 Radarsat2 verilerinden elde edilen) ile toprak nemi içeriği arasındaki ilişkinin diğer SAR veri sonuçlarından daha iyi olduğu bulunmuştur $(r=0.506, p<0.05)$.
\end{abstract}

Estimation of soil moisture by synthetic aparture radar (microwave) images in semi arid regions

\section{ABSTRACT}

Spatial and temporal distribution of soil moisture is a key parameter for agricultural applications at watershed level such as drought monitoring, crop irrigation scheduling, and yield estimations in arid and semi-arid regions. Moreover, radar satellite imagery systems have been used to figure out soil and vegetation distributions spatially and temporally for various regions. Estimation of surface soil moisture using active microwave sensor systems is among useful information for researchers, conservation planners, and decision makers pursuing sustainable use of natural resources. This study was carried out at the soils of selected sixty-four square kilometers test site in Altnova State Farm. It was aimed to determine the relationship between the surface soil moisture and the backscatter values of SAR images (Radarsat-2) obtained four different times. To that end, four SAR images (4 Radarsat-2 images) from Altınova State Farm were used. Surface soil samples were collected simultaneously from $0-20 \mathrm{~cm}$ depth at 730 different points with $250 \mathrm{~m}$-intervals, and soil moisture was determined using gravimetric method throughout the study area. In regards to each sampling period, surface soil moisture distribution maps were produced using ordinary kriging method. Considering the soil moisture distribution maps the data obtained in August indicated the most alterations in the surface soil moisture throughout the study

Anahtar Sözcükler:

Toprak Nemi

Radarsat-2

Konumsal Değişkenlik
Keywords: Soil moisture Radarsat-2 Spatial Variability

(C) OMU ANAJAS 2020 
area in comparison to the other sampling periods. Therefore, it was revealed that the relationship between backscattering (obtained from Radarsat-2 data in August, 2012) and soil moisture content was better than the other SAR data results $(r=0.506, \mathrm{p}<0.05)$.

\section{Giriş}

Toprak nemi, birçok hidrolojik ve doğal süreçlerin anlaşılmasında önemli bir etmendir. Arazi yüzeyi enerji dengesi ve taşkın süreçlerindeki rolü nedeniyle su bilimcileri, meteorologlar ve iklim bilimciler tarafindan çevresel süreçte anahtar bir parametre olarak kabul edilmektedir. Kurak ve yarı kurak bölgelerde, kuru tarım yapılan alanlarda yağışlar sonucunda infiltrasyonla toprağa giren su bitkisel üretim için tek kaynaktır. Sürdürülebilir bir tarımsal üretim için en önemli faktör olması nedeniyle doğru ölçülmesi ve izlenmesi kritik önem arz etmektedir (Lin ve ark., 2006a; 2006b; Gish ve ark., 2011).

Toprak neminin büyük alanlarda gravimetrik yöntemler ve diğer sensör ölçüm aletleri (TDR, FTIR, vs.) ile ölçülmesi ve izlenmesi (De Lannoy ve ark., 2006; Western ve ark., 2004; Kutilek ve Nielsen, 1994) zaman alıcı, masraflı ve iş gücü gerektirmesi nedeniyle pek mümkün değildir. Bununla birlikte cihazlar ile yapılan ölçümlerin hacimsel yöntemler ile kalibrasyona ihtiyaç göstermesi ve küçük alanlarda uygulanabilir olması nedeniyle, araştırmacıları büyük alanlarda (havza, bölgesel, ülkesel ölçeklerde) hızlı ve güvenilir olarak toprak nemini izlemek amaciyla uzaktan algılama çalışmalarına yöneltmektedir (Western ve ark., 1999; Gish ve ark., 2005; Lin ve Zhou, 2008).

Günümüzde bütün hava koşullarında, gece ve gündüz görüntü alabilme yeteneği, bulutluluktan etkilenmeme gibi çalışma prensipleri ve diğer özelliklerinden dolayı, RADAR veya SAR uydu verileri havza bazında yapılan hidrolojik döngülerin tanımlanmasında, toprak suyunun izlenmesinde, bitki örtüsü değişimlerinin izlenmesinde, ürün rekolte tahminlerinde ve bitki su tüketim çalışmalarında başarılı olarak kullanılmaktadır (Bayramin ve ark., 2013).

Radar görüntüleri çok geniş bir kullanıcı grubuna hizmet etmektedir. Tarım, orman, kartoğrafya, hidroloji, deniz biliminde (özellikle buzulların izlenmesinde), felaket ve kaynak yönetiminde, jeolojide, arazi örtüsü ve arazi kullanımı haritalarının oluşturulmasında, sahil ve deniz gözetiminde, güvenlik ve yabanc1 politikalarda yaygın olarak kullanılabilir. Radarsat-2 uydusu Kanada Uzay Topluluğu'nun uzaktan algilama teknolojileri ve uygulamalarını geliştirilmesinde de öncülüğünü kanıtlamaktadır. Dünyanın en gelişmiş radar görüntü sağlayıcısından biri olan Radarsat-2, yüzlerce uygulama için yüksek kalitede veriyi kullanıcılara sunmaktadır (Löw ve ark., 2005).

Toprak nem içeriğinin belirlenmesinde mikrodalga uzaktan algılamanın temel esası suyun ve kuru toprağın dielektirik özelliklerindeki zitlık ve Fresnel yansıma katsayısı ile dielektrik direnci arasındaki ilişkilerdir.
Havanın dielektrik sabitesi bilinen bir değer olduğu için yansıma katsayıs1, toprak ortamının dielektrik sabitinin ölçümünü vermektedir (Jackson ve ark., 1996). Shao ve ark., (2003), nemli ve tuzlu topraklarda dielektrik özelliklerinin gerisaçılım katsayısına olan etkisini RADARSAT-1 görüntüsü kullanarak belirlemişlerdir. Araştırmanın sonucunda RADARSAT-1 uydu görüntüsünden elde edilen gerisaçılım değerleri ile alınan toprak örneklerinin tuzluluk değerleri arasındaki korelasyon katsayısı 0,69 olarak belirlenmiştir. Walker ve ark. (2004) ERS-2 (European Remote Sensing) uydusunun düşey polarize SAR C-bandının yüzeye yakın toprak nemini ölçme potansiyelinin olduğunu belirtmiş̧lerdir. Ancak SAR gerisaçılmasının büyük bir oranda topoğrafyaya, toprak tekstürüne, yüzey pürüzlülüğüne ve toprak nemine bağlı olduğunu; tek bir frekans ve polarizasyon SAR gözlemleriyle toprak nem değişimini belirlemenin zor olduğunu bildirmişlerdir. ERS-2, RADARSAT ve ENVISAT (Environment Satellite) gibi uydularda bulunan C-band 1 radar sinyalleri yüzey toprak nemine duyarlıdır (Paloscia ve ark., 2005). C-bandı ölçümleri sadece toprak nemi tarafından değil; bitki örtüsü ve yüzey pürüzlülüğü tarafindan da etkilenmektedir. ENVISAT/ASAR verileri kullanılarak bitki örtüsüyle kaplı veya çıplak arazilerde toprak yüzey nemini belirlemeye yönelik pek çok istatistiki ve deneysel yöntem geliştirilmiştir (Alexander ve ark., 2006; Baghdadi ve ark., 2002; Boisvert ve ark.,1997; Beaudoin ve ark., 1990; Alvarez-Mazos ve ark., 2005; Zribi ve ark., 2005a ve 2005b; Siegert ve Ruecker, 2000; Oldak ve ark., 2003; Kelly ve ark., 2003; Baghdadi ve ark., 2006; Chen ve ark.,2007; Holah ve ark., 2005; Li, 2004). Hègarat-Mascle ve ark. (2000), ERS/SAR verilerinden yararlanarak toprak nemi ve SAR sinyalleri arasında doğrusal bir ilişki olduğunu tespit etmek için "Operational Metodology" kullanmışlardır. Çalışmayı iki aşamada yönetmişlerdir. Kalibrasyon aşamasında SAR sinyallerindeki vejetasyon etkisini çıkarmak için yer gözlemleme çalışması yapmışlardır. İkinci aşamada ise SAR verilerinden vejetasyon etkisi çıkararak, toprak nemi ile SAR sinyalleri arasında doğrusal bir ilişki olduğunu tespit etmişlerdir. Shakil ve ark. (2000), Chiba havzasında, çıplak toprak koşullarında radar verileri yardımıyla toprak nemini belirlemek için, HV, VV ve hiper spektral gibi üç doğrusal polarizasyon ve $150,230,350$ ve 450 dereceli görüntü alma açısına sahip C bandını ve yüzeyle ilgili özellikleri tanımlayabilmek için Integral Equation Modeli kullanmışlardır. Modelin deneysel verilerle ilişkili olduğunu ve $\mathrm{HH}$ polarizasyonda modelleme ile gözlenen geri yansıma katsayısı arasında iyi bir ilişkinin olduğunu bulmuşlardır. Toprak nemi ile ilgili konularda çalışma yapılırken, C- bant ve düşük açılı görüntüler alınması gerektiğini bildirmişlerdir. 
Fung ve Chen (1992), SAR verisinden elde edilen yansıma değeri, yüzey pürüzlülüğüne, toprak üzerindeki vejetasyonun özelliklerine ve toprağın nem içeriği gibi birçok faktöre bağlı olduğunu belirtmişlerdir. Vejetasyon olmadığı zaman ise radarın yansıma değerinin, toprağın su içeriğine ve yüzey pürüzlülüğüne bağlı olduğunu bildirmişlerdir. Wang ve ark. (2003), ERS-2 ve LANDSAT-TM uydu görüntüleri kullanarak yarı kurak iklim kuşağındaki arazilerde toprak nemini tahmin etmeye çalışmışlardır. Araştırmacılar, ERS-2/ LANDSAT-TM uyumu ile bitki örtüsü olan arazilerde toprak neminin belirlenmesinde, olumsuz yönde etkileyen parametreleri elimine etmeye çalışmışlardır. Yaklaşım olarak yüzey mikro-rölyefinin etkisini, geçici diferansiyel gerisaçılım katsayısını kullanarak düşürmüşler ve sonra optik/mikrodalga uyumu sağlanarak toprak nemi, normalize edilmiş vejetasyon indisi (Normalized Difference Vegetation Indice, NDVI) ve toplam gerisaçılım katsayısı arasındaki ilişkiyi ortaya çıkarmışlardır. Sonuçlar, yarı kurak iklim kuşağındaki alanlarda, radar gerisaçılımı kuru topraklarda oluşturulan NDVI ile pozitif korelasyon sağlamış, ancak toprak nemi yüksek olan alanlarda ise negatif korelasyon bulunmuştur.

Bu çalı̧̧mada, Radarsat-2 radar görüntüsü çekimi ile eş zamanlı olarak araziden alınan toprak örneklerinde gravimetrik nem analizi yapılmıştır. Radar verisinden elde edilen gerisaçılım değerleri ile toprak nemi arasındaki dört farklı zamanda (13 Aralık 2011, 26 Nisan, 28 Ağustos ve 4 Aralık 2012) değişim ortaya konulmaya çalışılmıştır.

\section{Materyal ve Yöntem}

\section{1 Çalışma Alanı}

$\mathrm{Bu}$ çalışma, Tarım İşletmeleri Genel Müdürlüğü'ne ait Altınova Tarım İşletmesi'nde $8 \times 8 \mathrm{~km}^{2}$ büyüklüğünde bir alanda yürütülmüsşür. İç Anadolu Bölgesinin 310 39' $20 "$ - 320 49' 55" Doğu boylamları ve 580 39' 20" - 510 41' 54" Kuzey enlemleri arasinda yer alan, ortalama deniz seviyesinden $915 \mathrm{~m}$ rakıma sahip olan Altınova Tarım İşletmesi arazileri, Konya İline bağlı Kadınhanı İlçesinin $60 \mathrm{~km}$ kuzeyinde, Ankara'ya $189 \mathrm{~km}$ ve Konya İline $126 \mathrm{~km}$ uzaklıktadır (Şekil 1). Kültür altındaki alanlarda buğday, arpa, tritikale, yonca, mısır gibi ürünler yetiştirilmektedir. Bunlar arasında buğday en fazla yetiştirilen üründür (Anonim 2019). İşletmede nadas ekim sistemi uygulanmaktadır.

Altınova Tarım İşletmesine ait 1999-2011 yılları arasındaki meteorolojik verilerine ve araştırma alanı topraklarının Soil Survey Staff (2015)'a göre sicaklık rejimi Mesic, nem rejimi ise Aridik olarak belirlenmiştir.

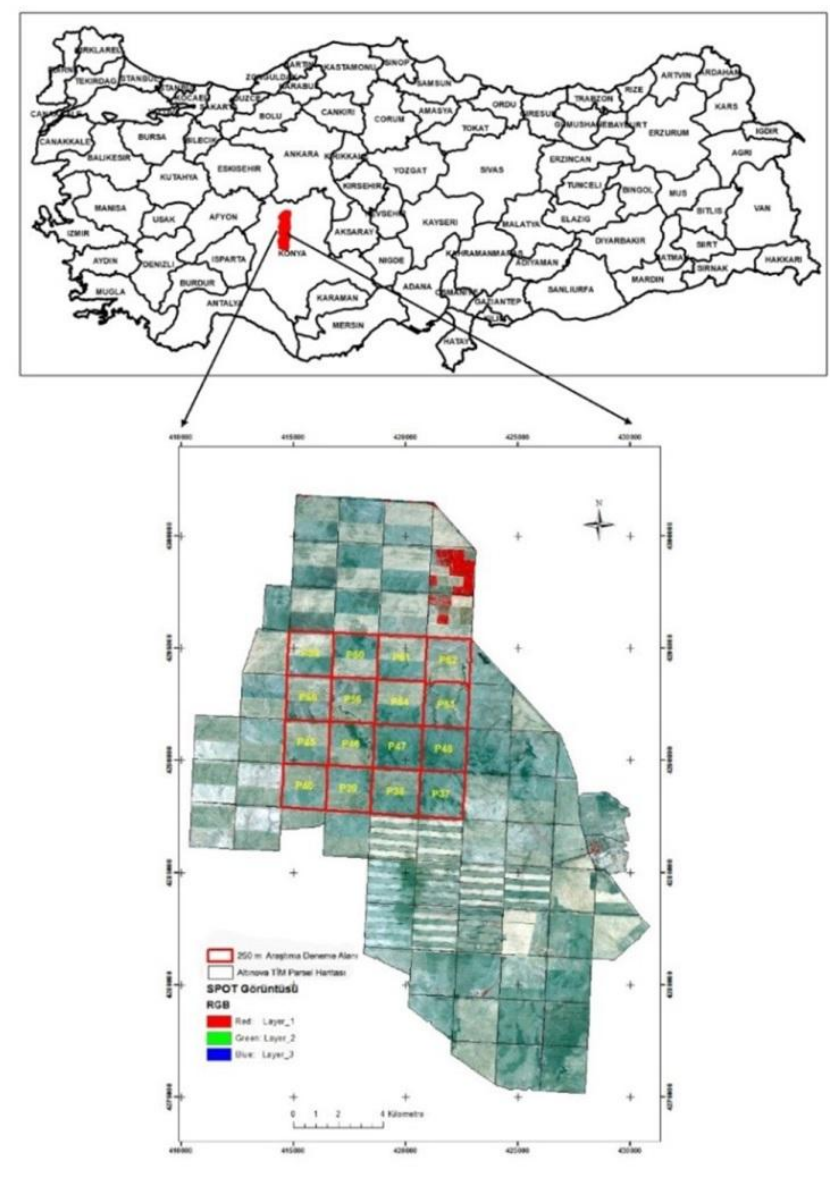

Şekil 1. Altınova Tarım İşletmesindeki çalışma alanının konumu ve parsel haritası

Figure 1. Location and parcel map of the study area in Altınova State Farm

\subsection{Yöntem}

Çalışma kapsamında 4 tarihte (13 Aralık 2011, 26 Nisan, 28 Ağustos ve 4 Aralık 2012) olmak üzere Radarsat-2 uydu görüntüsü ve bu görüntüler ile eş zamanlı olarak seçilen deneme alanında $250 \mathrm{~m}$ aralıklarla toprak örneklerinin alındığı arazi çalışması yapılmıştır. Arazi çalışması sırasında işletmedeki sulama yapılan parseller çalışma dışında bırakılarak, işletme topraklarının yaygın toprak serilerini içeren bir deneme alanı seçilmiştir. Seçilen deneme alanında 250 $\mathrm{m}$ aralıklı radar görüntüleri ile eş zamanlı olarak alınan toprak örneklerinde nem ölçümleri yapılmıştır (Şekil 2). Radar görüntülerinin alındığı tarihlerde arazide bitki örtüsü bulunmadığı veya çıplağa yakın durumda olduğu için bitki örtüsünün yansımaya (gerisaçılım) etkisi olmadığı düşünülmektedir. İnce dokulu bitki örtüsüne penetre olabilen, yaklaşı $5 \mathrm{~cm}$ dalga boyu aralıklı (C bant), mikrodalga boyundaki enerjinin gerisaçılımlarını içeren SAR uydu görüntüleri ile toprak neminin belirlenebilirliği araştırılmıştır. 


\subsubsection{Toprak Örneklemesi}

Araştırma alanı ekim sistemi, transektlerle birlikte $250 \mathrm{~m}$ aralıklı toprak örnekleme yerleri Şekil 2'de sunulmuştur. 2011 yılı Aralık ve 2012 Nisan aylarında yapılan toprak örnekleme çalışmaları sadece nadas alanlarında, 2012 Ağustos ve Aralık aylarında yapılan toprak örnekleme çalıșmaları ise deneme alanının tamamında yürütülmüştür (Şekil 2). Bu örnekleme takvimine göre, Aralık 2011 ve Nisan 2012 aylarında 730 noktada 1460 (730 x 2 ay) ve Ağustos ve Aralık 2012 tarihlerinde 1165 noktada 2330 (1165 x 2 ay) olmak üzere toplam 3790 toprak nem tayini yapılmıştır. Elde edilen sonuçların tanımlayıcı istatistikleri (ortalama, standart sapma, çarpıklık, basıklık, varyasyon katsayıs1, minimum ve maksimum olmak üzere) MINITAB 16 istatistik paket programı ile hesaplanmıştır. Elde edilen gravimetrik nem değerleri toprak örneklerinden elde edilen kuru hacim ağırlığı ve $20 \mathrm{~cm}$ toprak derinliği değerleri dikkate alınarak $\mathrm{mm}$ su derinlik cinsine çevrilmiştir. Deneme alanından toprak örneklerinde elde edilen kuru hacim ağırlığı değerleri (ortalama olarak 1,34 $\mathrm{gr} \mathrm{cm}^{-3}$, değişim katsayısı \% 3,37) 1,28 ile $1,45 \mathrm{gr} \mathrm{cm}^{-3}$ arasında bir değişim göstermektedir. Toprak örneklerindeki kil miktarları ise (ortalama olarak \%33,42 ve değișim katsayısı \%20,59) $\% 11,93$ ile 58,54 arasında değişim göstermektedir (Bayramin ve ark., 2013).

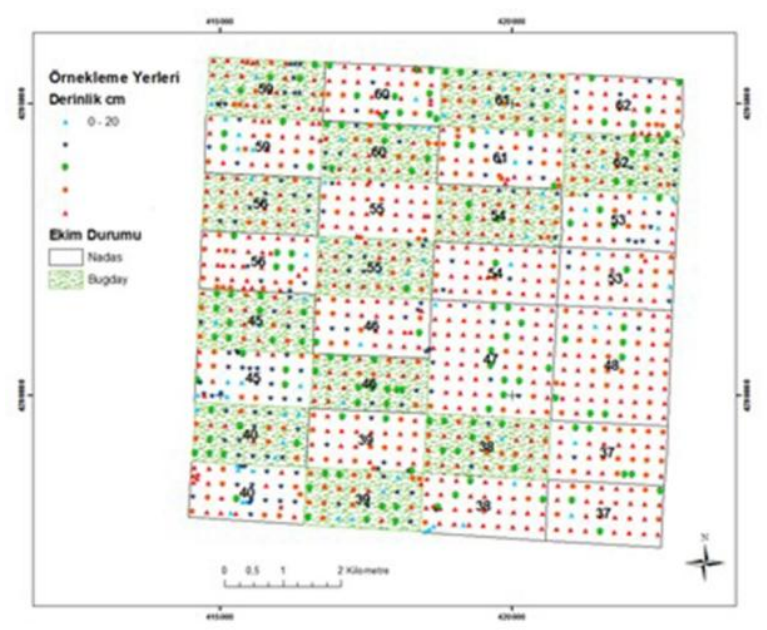

Şekil 2. Çalışma alanı toprak örnekleme noktaları

Figure 2. Soil sampling points in the study area

Proje çerçevesinde yapılan toprak nem analiz sonuçları doğrusal bir enterpolasyon tekniği olan kriging ile $0-20 \mathrm{~cm}$ derinlik için değerlendirilmiştir. Kriging yönteminde, örnekleme yapılmayan alanların tahmininde enterpolasyon yöntemini kullanılır, bu sırada örneklenen alanlardaki bilinen değerlerin ağırlıklı ortalamasından yararlanarak tahmin yapılmaktadır. Variogramın yapısal özellikleri ve örneklenmiş noktaları kullanarak örnek alınmamış noktalardaki bölgeselleştirmiş değişken optimum ve yansız olarak tahmin edilmektedir (Trangmar ve ark., 1985; Trangmar, 1987). Kriging matematiksel olarak Eşitlik 1 ve 2 'de verildiği gibi ifade edilebilmektedir.

$\mathrm{Z}_{0}=\sum_{i=1}^{n} Z_{i} * W_{i}$

Eşitlikte, $Z_{0}$ : Tahmin edilen değer; $Z_{i}$ : Ölçülen değer; $\mathrm{W}_{\mathrm{i}}$ : Ağırlığ 1 ifade etmektedir.

Ağırlık ise aşağıdaki gibi hesaplanmaktadır.

$\mathrm{W}_{\mathrm{i}}: \mathrm{C} / \mathrm{\Gamma}$

$\mathrm{W}_{\mathrm{i}}$ : Ağılık vektörü; $\Gamma$ : Variogram matrisi; $\mathrm{C}$ : Tahmin edilecek nokta ile tahminde kullanılacak örnekler arasındaki uzaklığa ilişkin varoigramları içeren vektördür.

Toprak nem değerlerinin uzaysal değişkenliğinin belirlenmesinde GS+7.0 programı kullanılmıştır. Hesaplanan her variogramda ayırma uzaklığı veya ayırma sayısında ayarlama yapılmıştır. Ayırmanın sonuç vermediği durumlarda bazı uç verilerin veri setinden uzaklaştırılması sağlanmıştır. Uygun variogram modelleri oluşturulmuş ve bu modeller kullanılarak her bir toprak nem değerleri için külçe etkisi $(\mathrm{C} 0)$, eşik değeri $(\mathrm{C} 0+\mathrm{C})$, yapısal uzaklık (A0) gibi variogram göstergeleri hesaplanmıştır (Çizelge 3). Toprak nem değerlerinin uzaysal değişkenliğinin belirlenmesi amacıyla elde edilen variogram göstergeleri kullanılarak ARCMAP 10.4 CBS yazılımı yardımıyla kriging yöntemine göre haritaları hazırlanmıştır.

\subsubsection{Radar Görüntüleri}

Altınova Tarım İşletmeleri arazileri içerisinde, işletme arazileri topraklarının büyük bir bölümünü temsil edecek şekilde $8 \times 8 \mathrm{~km}\left(64 \mathrm{~km}^{2}\right)$ boyutunda bir deneme alanı seçilmiştir. Bu deneme alanını kapsayacak şekilde 4 farklı tarihte (13 Aralık 2011, 26 Nisan, 28 Ağustos ve 4 Aralık 2012) Radarsat-2 görüntüsü SGF (SAR Georeferenced Fine) formatında alınmıştır. Radar görüntülerinin bazı özellikleri Çizelge1'de sunulmuştur.

Sayısal altlık haritaların oluşturulması, görüntü işleme aşamasının ilk bölümünü oluşturmaktadır. İşletmeye ait detaylı temel toprak haritası ve parsel haritası CBS yazılımı kullanılarak sayısallaştırılmıştır. Deneme alanına ait parsel haritası ve arazi çalışmaları sırasında parsellerin birleşme noktalarından yer kontrol noktalarının (YKN) koordinatları DGPS (Differential Global Positioning System) kullanılarak kaydedilmiştir. Çizelge 1'de her bir döneme ait çözünürlük ve diğer özellikleri detaylı bir şekilde sunulan radar görüntülerinin rektifikasyonunda bu noktalar yaklaşık 1 
Çizelge 1. Radarsat2 görüntülerinin bazı özellikleri

Table 1. Some Characteristics of Radarsat-2 images

\begin{tabular}{rccrccc}
\hline \multicolumn{1}{c}{ Tarihler } & $\begin{array}{c}\text { Sensör } \\
\text { Tipi }\end{array}$ & Polarizasyon & $\begin{array}{c}\text { Çözünürlük } \\
(\mathrm{m})\end{array}$ & $\begin{array}{c}\text { Tayfsal } \\
\text { Çözünürlük }\end{array}$ & Format & $\begin{array}{c}\text { Işın } \\
\text { Modu }\end{array}$ \\
\hline 13.12 .2011 & SAR & VV & 7,06 & C Band, $0,055 \mathrm{~m}$ & SGF, SLC & MLF \\
26.04 .2012 & SAR & VV & 1,84 & C Band, $0,055 \mathrm{~m}$ & SGF, SLC & UF \\
28.08 .2012 & SAR & VV & 1,79 & C Band, $0,055 \mathrm{~m}$ & SGF, SLC & UF \\
4.12 .2012 & SAR & VV & 1,81 & C Band, $0,055 \mathrm{~m}$ & SGF, SLC & UF \\
\hline
\end{tabular}

UF: Ultra-fine resolution beam, MLF: Multi-fine resolution beam, SGF: SAR Georeferenced Fine product, SLC: Single Look Complex

piksel $(1,84 \mathrm{~m})$ dikkate alınarak PCI- Geomatics yazılımında "geocoding" işlemi yapılarak gerçekleştirilmiştir. Radar görüntüleri "speckle noise" olarak tanımlanan birçok görüntü kirliliği içermektedir. $\mathrm{Bu}$ nedenle bu görüntülerde geo-rektifikasyon işleminden sonra çeşitli filtreleme uygulamaları yapılmaktadır. Matematik modele dayalı filtrelemeler bulunmaktadır. Gamma ve Lee filtreleme modelleri görüntü kirliliğinde en çok kullanılan yöntemlerin başında gelmektedir (Eliason ve McEwev, 1990; Huang ve Genderen, 1996). Bu çalışmada alınan radar görüntülerine Lee ve Gamma filtreleme işlemleri uygulanmıştır Araştırmada kullanılan, georektifikasyonu ve görüntü kirliliği giderimi işlemi yapılmış radar görüntülerinde, toprak nem örnekleme noktalarına ait koordinat bilgileri o döneme ait görüntüler üzerine girilerek, ilgili noktalardaki gerisaçılım (backscatter) değerleri belirlenmiştir. Deneme alanındaki $250 \mathrm{~m}$ nem örnekleme noktalarının gerisaçılım değerleri, sigmanought dönüşümleri yapıldıktan sonra belirlenmiştir. $\mathrm{Bu}$ amaçla nem örnekleme noktaları çevresine 33 m'lik bir tampon hattı oluşturulmuştur, oluşan alan içerisindeki merkez piksel ve çevresindeki pikselin ortalama değeri gerisaçılım değeri olarak kabul edilmiştir. Bu işlemin yapılması için PCI-Geomatics ve Nest DAT 5.0.16 yazılımları kullanılmıştır. Wang (1980), radar gerisaçılım katsayısı (backscatter) ile toprak nemi arasında bir ilişki olduğunu saptamıştır.

Radar yansıması gerisaçılım şeklinde olup lokal geliş açısına bağlı olan sigmanought $(\sigma 0)$ değerleri ile ifade edilmektedir. "Sigmanought " değeri, ortalama gerisaçılım (backscatter) değerinin alım açısına oranlanması ile elde edilir. Sigmanought değeri aynı zamanda saçılma katsayısı olarak da ifade edilmektedir. Sigmanought $(\sigma 0)$ değerinin büyüklüğü hedefin/objenin fiziksel ve elektriksel özelliklerine, SAR sisteminin dalga boyu ve polarizasyonuna ve alım açısına bağlıdır. Alım açısı ise her noktadan yüzeyin lokal eğimine bağlı olarak değiş̧iklik göstermektedir. Aşağıda sunulan eşitlik SAR görüntülerinde her bir piksele ait gerisaçılım değerlerinin sigmanought değerlerine dönüşümünü göstermektedir (Eşitlik 3 ve 4).

$$
\begin{aligned}
& \beta^{0}=10^{\log _{10}\left[\frac{(D N 2+A 3)}{A 2}\right]} \\
& \sigma^{0}=\beta^{0}+10^{\log _{10}(\sin I)}
\end{aligned}
$$

Eşitlikte; $\beta 0$ : betanought değerleri, $\sigma^{0}$ : sigmanought değerleri, DN2: SAR görüntülerinin her bir pikseline ait sayısal değerleri; A3: Radyometrik kayıttan olan öteleme; A2: Görüntünün ekrandaki (Look Up Table = LUT) değerlerini ifade etmektedir.

Araştırmada 4 farklı tarihte alınan Radarsat2 görüntüleri için sigmanought dönüşümleri yapılmıştır. Elde edilen değerler ile toprak nem miktarı arasındaki ilişki incelenmiştir. Değerlendirme sırasında radardan elde edilen gerisaçılım ve nem değerlerinin tanımlayıcı istatistikleri de hesaplanmıştır.

\section{Bulgular ve Tartışma}

$\mathrm{Bu}$ çalışmadan elde edilen sonuçlar toprak nem örnekleme sonuçları, radar ile ilgili görüntü analizleri ve radar- toprak nem ilişkisi (gerisaçılım değerleri-toprak nemi) olmak üzere 2 başlık altında toplanmaktadır.

\subsection{Toprak Nem Örneklemesi}

Deneme alanından dört farklı dönem olarak (Aralık 2011, Nisan 2012, Ağustos 2012 ve Aralık 2012 olmak üzere) alınan toprak örneklerinin nem içerikleri su kalınlığ 1 cinsinden $(\mathrm{mm})$ değerlerine ait tanımlayıcı istatistikleri Çizelge 2'de sunulmuştur.

En düşük nem ortalaması 1,56 mm ile Ağustos 2012 toprak nem örneklemesinde, en yüksek nem ortalaması 2,26 mm ile Nisan 2012 toprak nem örneklemesinde belirlenmiştir. Bununla birlikte, en küçük ve en büyük nem değişimlerinin en fazla olduğu, standart sapmanın en yüksek olduğu ay ise Nisan ayıdır. En düşük nem değeri ise Ağustos 2012 toprak nem örneklemesinde belirlenmiş̧ir. Wilding (1985)'e göre değişkenlik katsayıs1 \%15 den az olanlar düşük, \%15-35 arası olanlar orta ve \%35 den fazla olanlar ise değişkenliği yüksek olarak değerlendirilmektedir. Buna göre deneme alanındaki dört farklı dönemde alınan yüzey toprak nem değişimlerindeki değişkenlik katsayısı \%35 den fazla olması nedeniyle yüksek değişkenlik gösterdiği belirlenmiştir. Buna paralel olarak dört nem örnekleme 
döneminde de çarpıklık değerinin 0 altında olması nedeniyle sola çarpık ve normal dağılıma göre daha

basık (-) dağılımlar elde edilmiştir.

Çizelge 2. Su kalınlığı cinsinden (mm) toprakta nem örneklemelerinin tanımlayıcı istatistikleri

Table 2. Descriptive statictics of soil moisture samples in terms of water depth

\begin{tabular}{ccrrrrrr}
\hline Tarihler & \multicolumn{1}{c}{ Ort. } & \multicolumn{1}{c}{ Std. S. } & \multicolumn{1}{c}{ EDD } & \multicolumn{1}{c}{ EYD } & DK $(\%)$ & \multicolumn{1}{c}{ Çarpıklı* } & Basılık \\
\hline 01.12 .11 & 1,83 & 66,3 & 0,397 & 4,05 & 36,2 & $-0,31$ & $-0,05$ \\
01.04 .12 & 2,26 & 85,8 & 0,334 & 4,296 & 37,9 & $-0,62$ & $-0,63$ \\
01.08 .12 & 1,56 & 81,7 & 0,073 & 3,215 & 52,3 & $-0,06$ & $-1,12$ \\
01.12 .12 & 1,93 & 79,0 & 0,322 & 3,789 & 40,9 & $-0,2$ & -1 \\
\hline
\end{tabular}

Std S: Standart Sapma; EDD: En düşük değer; EYD: En yüksek değer; DK: Değişkenlik Katysayıs1

$*$ Çarpıklık $<| \pm 0.5|=$ Normal Dağılım, 0.5-1.0 = Veri setine karekök dönüşümü uygulanır. ÇK $>1.0 \rightarrow$ Logaritma dönüşümü uygulanır.

Çizelge 3.Toprak nem örneklemelerine ait jeoistatistik variogram parametreleri

Table 3. Geostatistical variogram parameters of soil moisture samples

\begin{tabular}{ccccc}
\hline Tarihler & Model & Co & Co+C & A \\
\hline Aralık 2011 & Üstel. & 41,7 & 83,41 & 954 \\
Nisan 2012 & Üstel & 14,8 & 68,91 & 1140 \\
Ağustos 2012 & Üstel & 71,6 & 195,5 & 1513 \\
Aralık 2012 & Üstel. & 33,1 & 87,66 & 1764 \\
\hline
\end{tabular}

Co: kontrolsüz etki varyansı; Co+C: tepe varyansı; A: etki aralığı (m)

Deneme alanı nem değerlerinin dağılımları variogram parametreleri kullanılarak CBS yazılımı kullanılarak haritalanmış ve Şekil 3 'te sunulmuştur.

Şekil 3'ten de görüldüğü gibi ekili parsellerdeki nem değerleri nadas parsellerine göre daha düşük nem değerleri göstermiştir. Benzer şekilde, Bayramin ve ark. (2013), Altınova Tarım İşletmesi'nde $1 \mathrm{~km}$ aralıklar ile ekili ve nadas alanlarında farklı derinliklerde yaptıkları toprak nem örnekleme sonuçlarına göre işletme genelinde kurak iklim koşullarına sahip olan bu bölgede nadas sistemi bitki gelişimine olumlu etki yaparak katk1 sağladığını bildirmişlerdir. Buna ilaveten, nem değişim haritalarının sınırları ile toprak derinliği arasında bir uyum olduğunu bildirmişlerdir. Çalışmada toprak derinliğinin daha fazla olduğu alanlarda (Altınova, Kıllar Köyü, Hacıfakıll, İmamoğlu ve Çatalca serilerinin bulunduğu alanlar) elden edilen nem değerlerinin, toprak derinliğinin sığ olduğu alanlardan (Başkuyu, Kap ve Odabaşı serilerinin olduğu alanlar) daha fazla olduğunu bildirmişlerdir. Başka bir deyişle, toprak nemi ile araştırma alanı toprak haritası birlikte değerlendirildiğinde toprak haritalama birimleri ile örtüssen alanlar olduğu görülmektedir. Bununla birlikte bazı alanlarda uyumsuzluklar gözlemlenmiştir. Arazi çalışmaları sırasında yapılan gözlemlere dayanarak, uyumsuzluk gösteren bu alanların işletme yönetiminden kaynaklı olduğu, bazı alanlarda anız bozmanın çok geç yapılması nedeniyle, toprak neminin kaybının olduğu, toprak katmanının derin olmasına rağmen bu alanlarda daha az su depolandığ görülmüştür. Nisan - Ağustos 2012 tarihlerinde yapılan çalışma verileri alınarak yapılan nem değişim sınırları ile toprak haritalama birimleri arasında uyumluluk gözlenmiş ve Şekil 4'te sunulmuştur. 

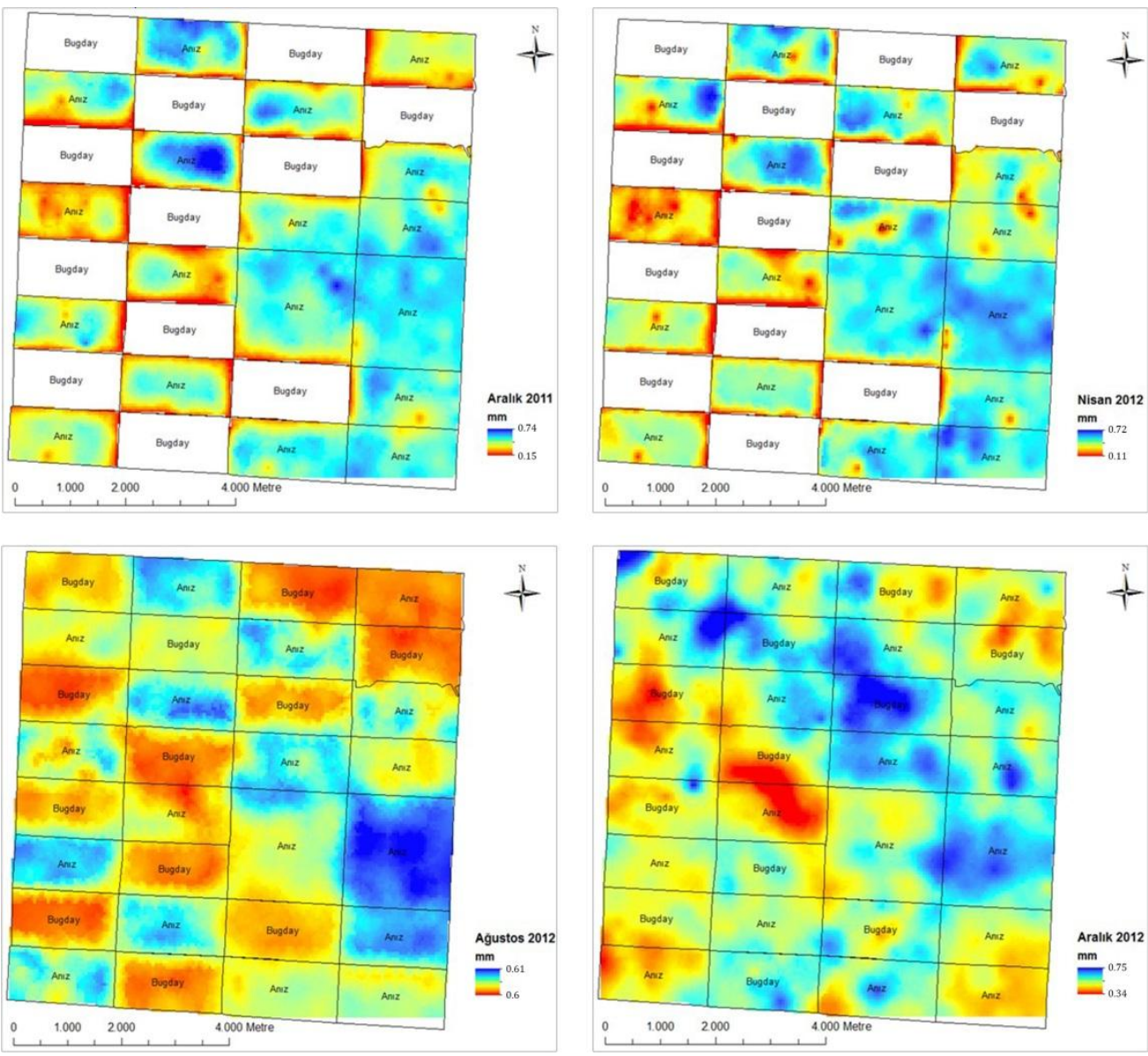

Şekil 3. Deneme alanındaki toprak nem dağılımları

Figure 3. The distribution of soil moisture in the study area

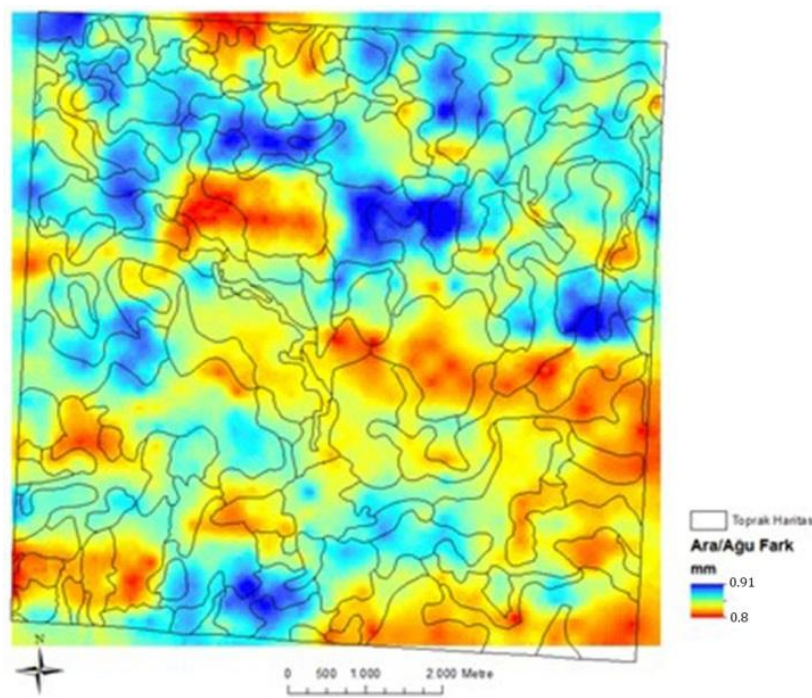

Şekil 4. 2012 Nisan - Ağustos toprak nem yüzeyleri ile yapılan değişim analizleri ile toprak haritalama birimlerinin gösterimi

Figure 4. Demonstration of variation analyses on soil moisture surfaces and soil mapping units in April/August 2012

\subsection{Radar İle Illgili Görüntü Analizleri ve Gerisaçılım Değerleri ile Toprak Nemi İlişkileri}

Altınova Tarım İşletmesi arazilerinde seçilen deneme alanına ait dört farklı zamanda siparişli çekilen radar görüntülerinde yöntem kısmında belirtildiği şekilde geo-rektifikasyon ve görüntü kirliliği analizleri yapılmıştır (Şekil 5, Şekil 6, Şekil 7 ve Şekil 8). Görüntü kirliliği analizi ile elde edilen görüntülerde (Şekil 5, Şekil 6, Şekil 7, Şekil 8) orjinal sigma görüntülerine filtre uygulamaları ile orjinal gerisaçılım değerlerinde herhangi bir değişikliğe yol açmamakla birlikte detay ayrımlarını görsel açıdan zenginleştirilme yoluna gidilmiştir. Deneme alanına ait elde edilen zenginleştirilmiş görüntülerde siyah, beyaz ve gri tonları, doku (texture) ve desen (pattern) özellikleri yorumlanabilmektedir. Bu renk tonları, yüzeyin nem durumu ile ilgili bilgi vermektedir. Diğer bir ifadeyle; deneme alanından alınan radar görüntülerindeki gri ton değerleri, yollanan enerjinin miktarına ve bu enerjinin yüzeyden gerisaçılımına bağlı olarak değişir (Narayanan ve Hirsave, 2001; Baghdadi ve ark., 2006). Yüzeyin nem içeriği arttıkça (kış ayları radar görüntüsü ve/veya yağışlı dönemlerde alınan görüntülerde, Şekil 5, Şekil 6, 
Şekil 8) yansımanın olması nedeniyle zayıf bir gerisaçılım olacak ve bu bölgelerden koyu bir görüntü elde edilmiştir. Yüzeyin nem içeriğinin daha az olduğu (yaz aylarında, Şekil 7) dönemlerde alınan radar görüntüsünde ise daha açık bir görüntü elde edilmiştir.

Radar sistemi ile görüntü alınacak yüzey arasındaki etkileşim radar sisteminin (frekans, polarizasyon, alım açısı) ve yer yüzeyinin ( arazi örtüsü, topografya ve rölyef vb) özelliklerini de içine alan birçok parametreye bağlıdır. Deneme alanından elde edilen görüntülerdeki gri renk tonları bu değişkenlerin birleşiminin bir sonucudur, dolayısıyla tüm bileşenlerin tek tek etkisini belirlemek çok güçtür. Radar görüntülerindeki gri ton değerlerinin belirlenmesinde nem değerinden sonra en etkili parametre yüzey pürüzlülüğüdür (Sano ve ark., 1998; Shao ve ark., 2003). Yüzeye ait yükseklik değişiklikleri radar dalga boyundan küçük ise o yüzey pürüzsüz olarak algılanırken, yükseklik değişiklikleri dalga boyuna ulaştığında yüzey pürüzlü olarak algılanmaktadır. Yükseklik değişiklikleri $\mathrm{cm}$ bazında ölçülmektedir. Pürüzlü yüzeyde gelen enerjiyi saçılmadan yansıtırlar ve gönderilen enerjinin küçük bir miktarı algılayıcıya dönmektedir. Yani pürüzsüz yüzeyler radar görüntülerinde koyu renk görünmesine neden olurken, pürüzlü yüzeyler gelen enerjiyi eşit miktarda saçmaları sonucunda daha açık tonlarda görünmektedirler (Dobson ve ark., 1985; Dubois ve ark., 1995; McNaim ve ark., 2010) . Deneme alanından elde edilen görüntülerde nadasa bırakılan arazilerde suyun toprakta depolanması için yapılan birleme, ikileme ve üçleme olmak üzere yapılan sürme işlemleri sonucu parsellerde yüzey pürüzlülüğün artmasına ve dolayısıyla daha açık renkler elde edilmesine neden olmuştur (Şekil 5, Şekil 6, Şekil 7 ve Şekil 8). Bununla birlikte aynı deneme alınan radar görüntülerinde ise sözkonusu parsellerde suyun depolanmasına bağlı olarak nem miktarı artmakta ve daha koyu bir görüntü alınmasına neden olmuştur.
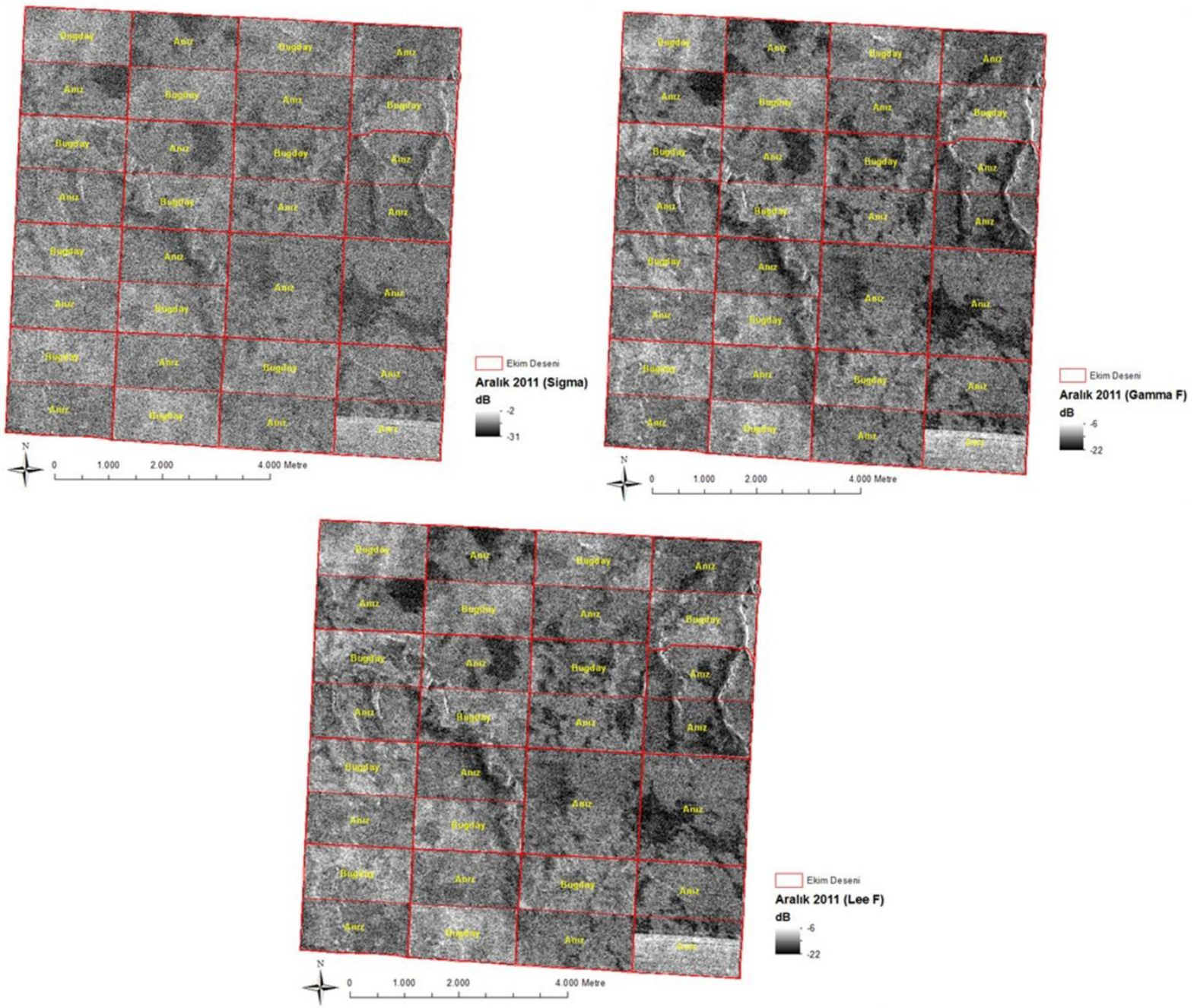

Şekil 5. Aralık 2011 tarihinde alınan radar görüntüsünün geo-rektifikasyon ve filtreleme sonrası görünümleri Figure 5. Georectification and post-filtration images of the radar display taken on 5 December 2011 

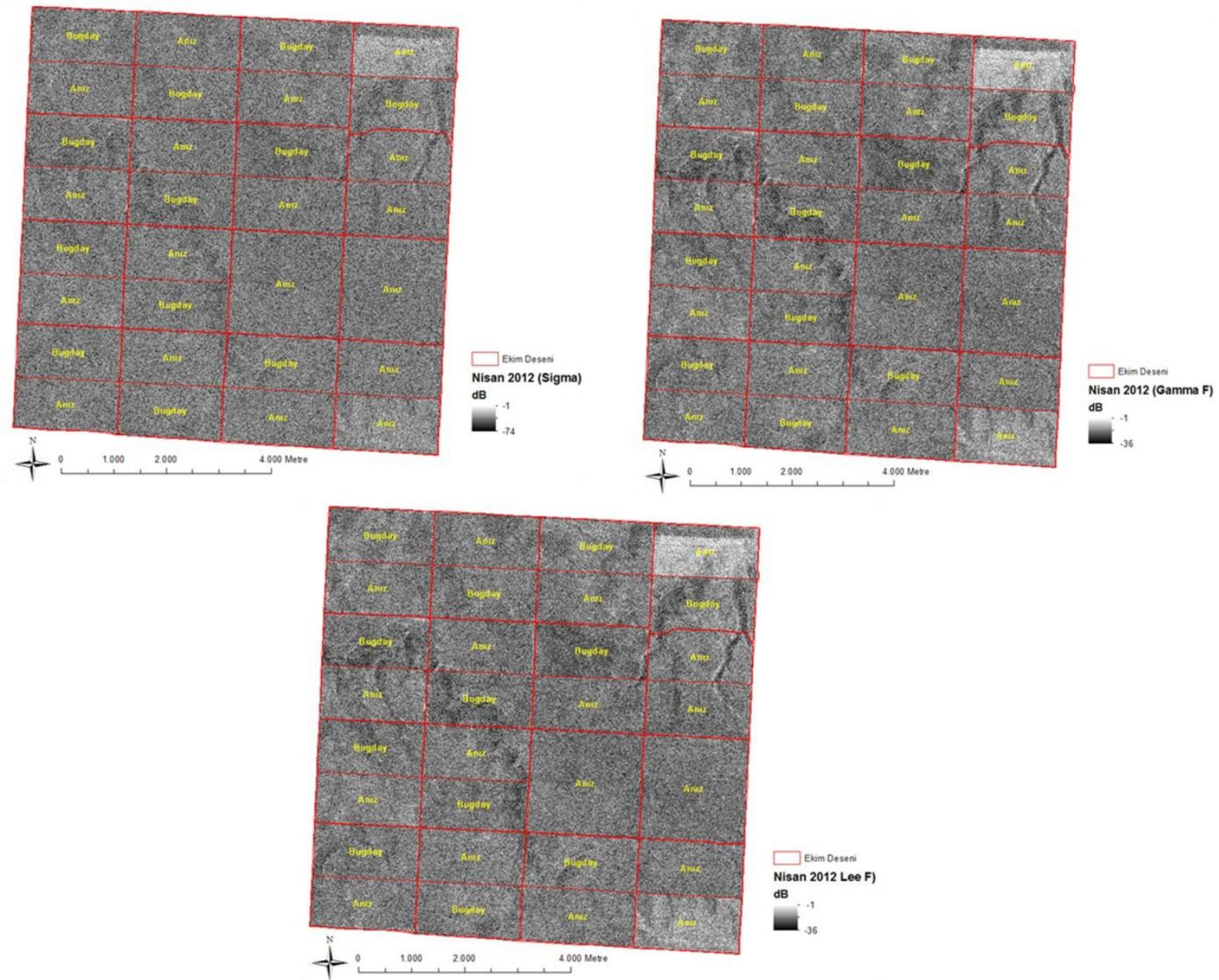

Şekil 6. Nisan 2012 tarihinde alınan radar görüntüsünün georektifikasyon ve filtreleme sonrası görünümleri Figure 6. Georectification and post-filtration images of the radar display taken on 6 April 2012 

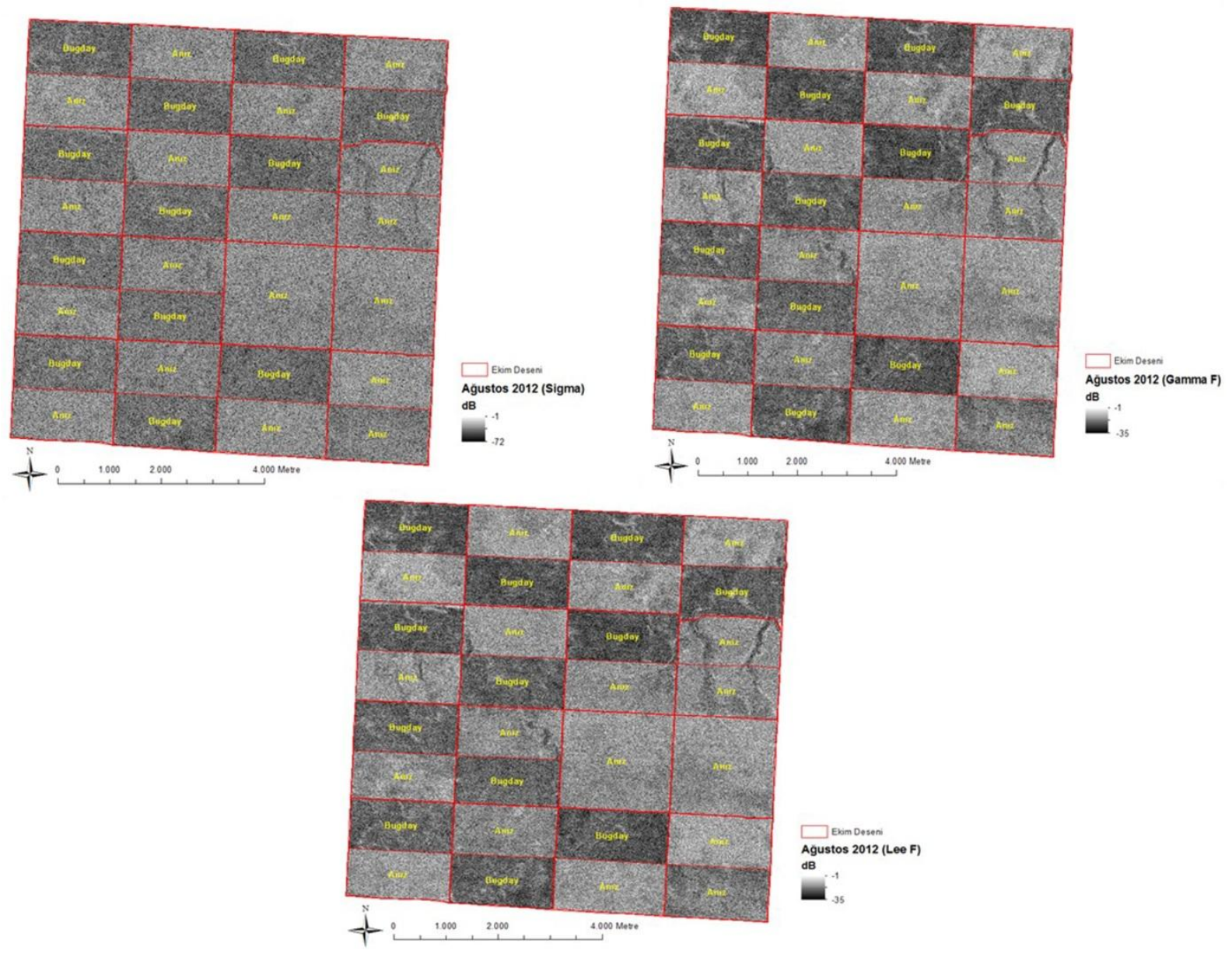

Şekil 7. Ağustos 2012 tarihinde alınan radar görüntüsünün georektifikasyon ve filtreleme sonrası görünümleri Figure 7. Georectification and post-filtration images of the radar display taken on 7 August 2012 

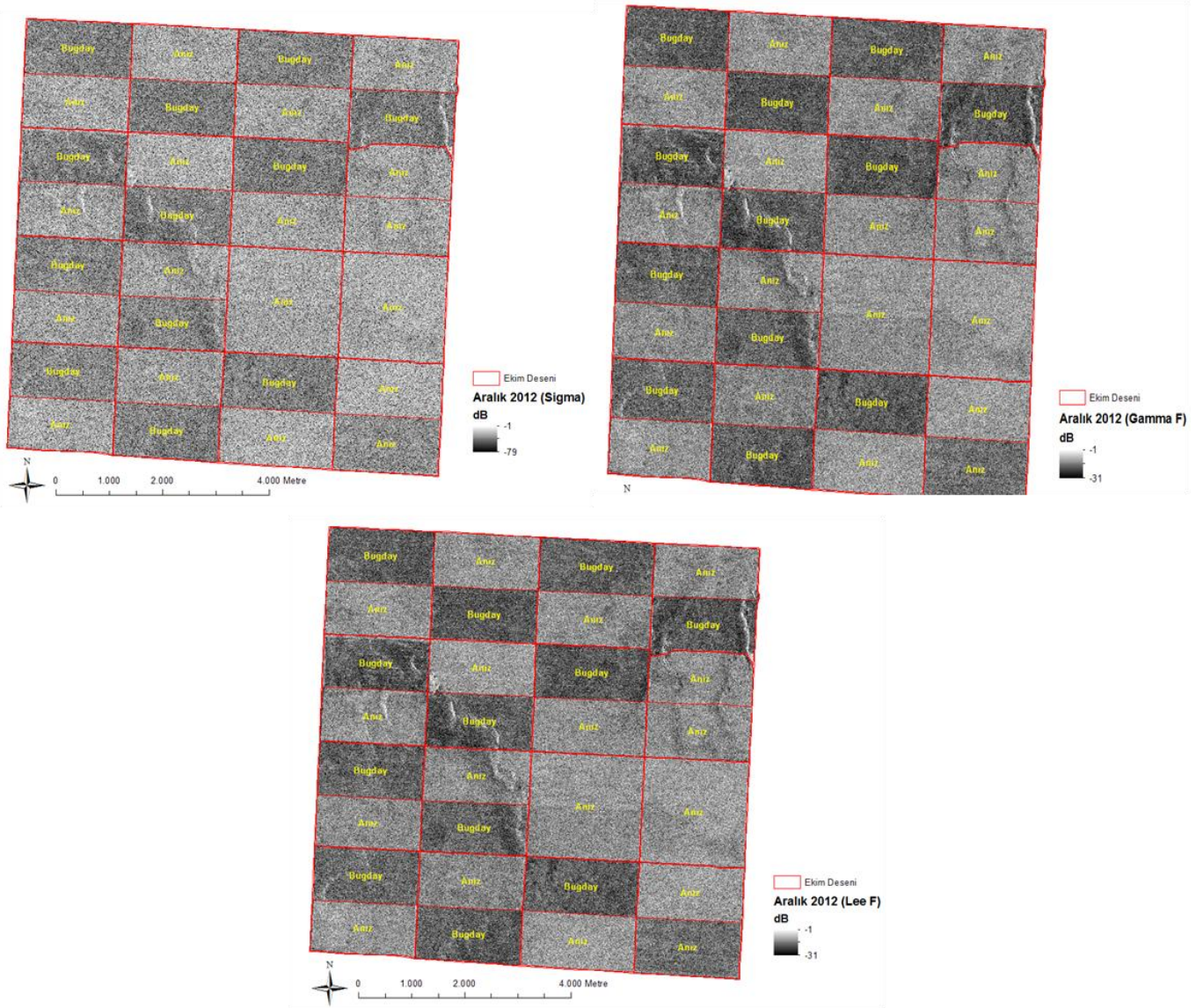

Şekil 8. Aralık 2012 tarihinde alınan radar görüntüsünün georektifikasyon ve filtreleme sonrası görünümleri Figure 8. Georectification and post-filtration images of the radar display taken on 8 December 2012

Toprak neminin dielektrik katsayısı mikrodalga enerjinin yanısmasını (gerisaçılımı) etkileyen en önemli faktörlerden olduğu birçok araştırmacı tarafindan vurgulanmıştır (Eliason ve McEwev, 1990; Huangg ve Genderen, 1996).Bu çalışmada yüzey toprak nem değişim haritaları dört farklı dönem için elde edilmiş ve aynı dönemlere ilișkin radar görüntüsünden gerisaçılım değerleri üretilmiştir. ARCMAP 10.4 CBS yazılımı kullanılarak toprak nem ölçüm noktaları çevresinde 33 m'lik tampon alanlar oluşturularak (Şekil 9) bu alanlardaki gerisaçılım değerlerinin ağırlıklı ortalaması hesaplanarak (Esetlili, 2008) toprak nem değerleri ile arasındaki ilişki ortaya konulmuştur.

Aralık 2011 tarihli Radarsat-2 uydu görüntüsünden elde edilen gerisaçılım değerleri ile toprak nem değerleri arasında negatif yönde ve istatistiksel olarak önemli düzeyde ilişki belirlenmiştir $(\mathrm{r}=-0,166, \mathrm{p}<$ 0,05 ) (Şekil 10, Çizelge 4). Bununla birlikte, radar görüntülerinde, yüzey pürüzlülüğü, bitki örtüsü ve toprak nemliliği ile ilgili olan yansıma bileşenleri ayırmak oldukça güçtür. Ancak kısa süreli izlemelerde pürüzlülüğün neden olduğu değişiklik nem değișiklik etkisiyle ile kıyaslandığında ihmal edildiğini bilinmektedir (FAO 1993; Esetli 2009).

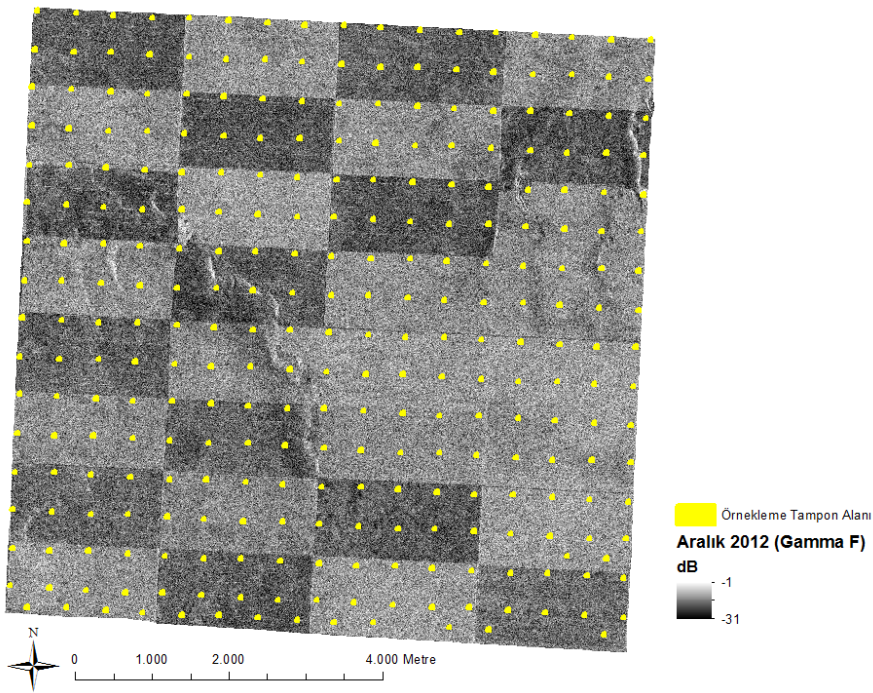

Şekil 9. Radarsat2 görüntüleri ile toprak nem yüzeyleri ilişkilendirmek için seçilen $999 \mathrm{~m}^{2}$ lik $(33$ x 33 m) tampon alanları

Figure 9. $999 \mathrm{~m}^{2}(33 \times 33 \mathrm{~m})$ buffer zones chosen to associate Radarsat-2 images and soil moisture surfaces 
Elde edilen sonuçlar, toprak neminin daha fazla olduğu dönemlerde radardan elde edilen gerisaçılıma nemin daha etkili olduğunu göstermektedir. Wang ve ark. (2004) yarıkurak alanlarda radar görüntüleri gersaçılma değerleri ile nem değerleri arasında ilişki bulmak için San Pedro Nehir havzasında yürüttükleri çalışmalarında toprak nem düzeyinin \% 10 'dan fazla olduğu durumlarda negatif ilişkinin olduğunu, bununla birlikte $\% 10$ 'dan daha az nem içeriğine sahip olduğu durumlarda pozitif bir ilişkinin olduğunu bildirmiş̧lerdir. Verhoest ve ark. (1998) kış döneminde bitki gelişiminin çok az olması veya olmaması çok zamanlı olarak alınan radar görüntülerinden elde edilen gerisaçılımların toprak nemi ve yüzeyin drenaj koşulları ile ilişkili olduğunu, ancak ilişkinin yanı sıra yüzey pürüzlülüğünün de önemli bir faktör olduğunu vurgulamışlardır.

Çizelge 4. Toprak nem değerleri ile Aralık 2011 tarihli Radarsat-2 görüntüsü sigmanought değerleri tanımlayıcı istatistik verileri

Table 4. Descriptive statisticals of soil moisture values and sigmanought values of Radarsat-2 image dated December 2011

\begin{tabular}{crcr}
\hline Toprak Nemi (mm, su kalınlığı) & Geri saçılım $(\mathrm{dB})$ & \\
\hline Örnek sayısı & 730 & Örnek sayısı & 730 \\
Ortalama & 0,535 & Ortalama & $-15,74$ \\
En düşük & 0,15 & En düşük & $-19,99$ \\
En yüksek & 1,14 & En yüksek & $-10,95$ \\
Ortanca değer & 0,52 & Ortanca değer & $-15,67$ \\
Standart sapma & 10,47 & Standart sapma & 1,27 \\
Değişim Katsayısı & 19,58 & Değişim Katsayısı & $-8,09$ \\
Basıklık & 2,89 & Basılık & 0,47 \\
Çarpıklık & 0,65 & Çarpıklık & $-0,02$ \\
\hline
\end{tabular}

Toprak Nemi (su kalınlığı, mm)

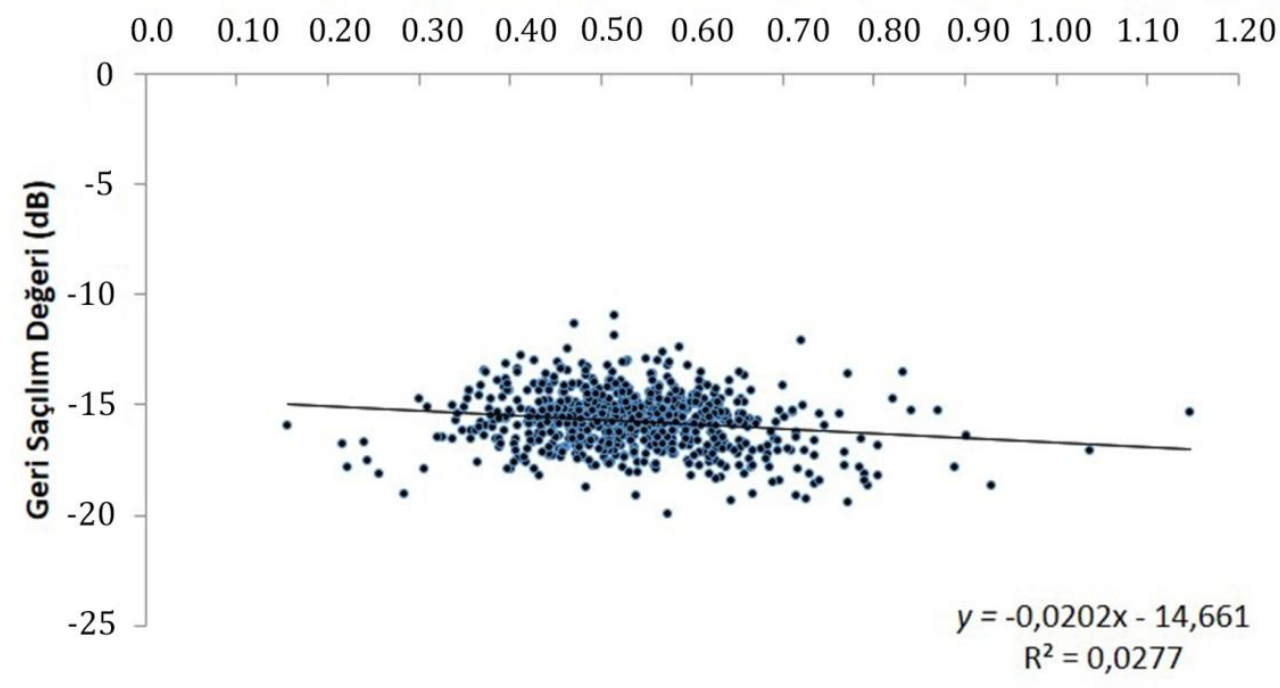

Şekil 10. Toprak nem değerleri ile Aralık 2011 tarihli Radarsat-2 görüntüsü sigmanought verileri arasındaki istatistiksel ilişki

Figure 10. Statistical relationship between soil moisture values and sigma nought data of Radarsat-2 image dated December 2011

Nisan 2012 tarihli Radarsat-2 uydu görüntüsünden elde edilen gerisaçılım değerleri ile toprak nem değerleri arasında istatistiksel olarak önemli düzeyde ilişki belirlenmemiştir (Şekil 11, Çizelge 5). Nisan ayında ekili alanlardaki buğday çıkışına (bitki örtüsüne) bağlı olarak nem değerleri ile gerisaçılım değerleri arasında iliş̧i bulunamadığı düşünülmektedir. Moran ve ark. (2000), kurak iklim koşullarında yaptıkları 
çalışmada Radarsat1, ERS-2 ve Landsat-5 optik uydu görüntüleri kullanmışlardır. Çalışmada SAR gerisaçılımının uydu alıcılarının görüntüyü aldıkları açı ( $\theta$ ) ile doğrudan ilişkili olduğunu, bununla birlikte bitki yoğunluğundan, topoğrafik özelliklerden ve mikrorölyefden de etkilendiğini bildirmişlerdir. Deneme alanındaki bitki çıkışları gerisaçılım değerleri ile nem değerleri arasındaki ilişkiyi daha karmaşık hale getirmiştir.

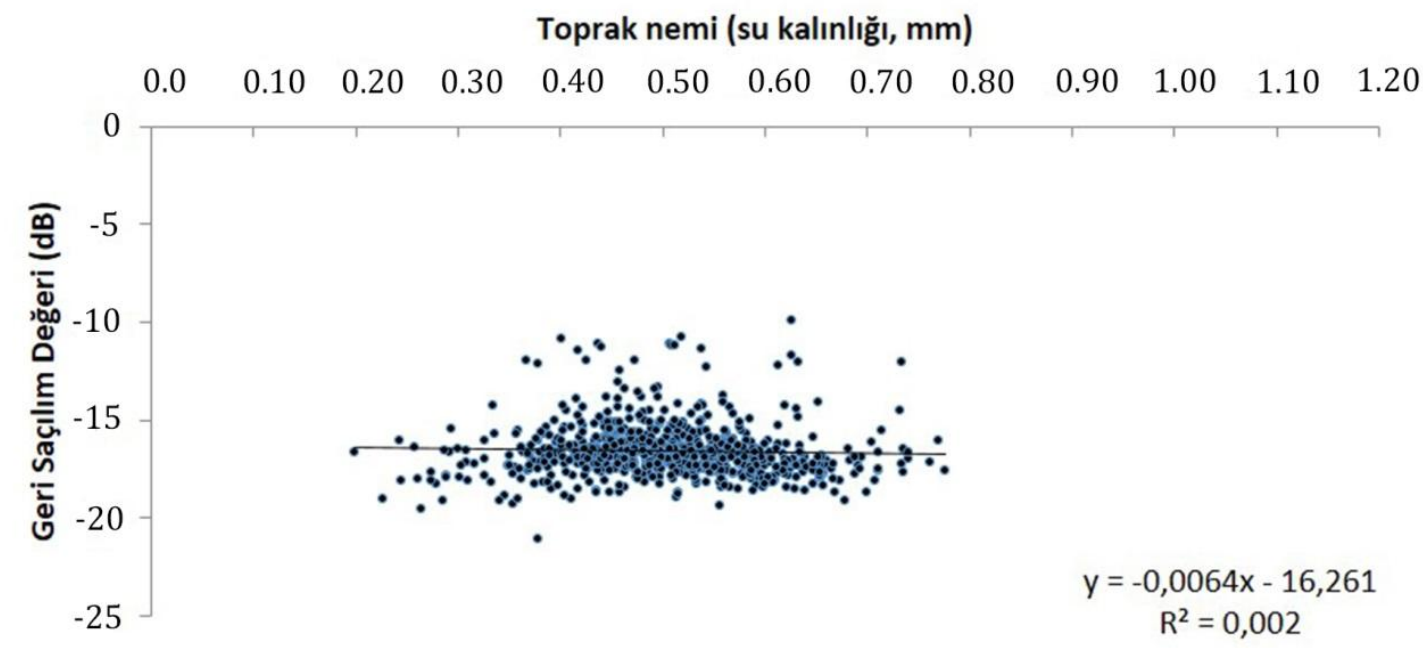

Şekil 11. Toprak nem değerleri ile Nisan 2012 tarihli Radarsat-2 görüntüsü sigmanought verileri arasındaki istatistiksel ilişki

Figure 11. Statistical relationship between soil moisture values and sigma nought data of Radarsat-2 image dated April 2012

Çizelge 5. Toprak nemi ile Nisan 2012 tarihli Radarsat-2 görüntüsü sigmanought değerleri tanımlayıcı istatistikleri Table 5. Descriptive statistical of soil moisture and sigmanought values of Radarsat-2 image dated April 2012

\begin{tabular}{cccc}
\hline \multicolumn{2}{c}{ Toprak Nemi (mm, su kalınlığı) } & Geri saçılım $(\mathrm{dB})$ & \\
\hline Örnek sayısı & 729 & Örnek sayısı & 729 \\
Ortalama & 50,55 & Ortalama & $-16,58$ \\
En düşük & 19,82 & En düşük & $-21,03$ \\
En yüksek & 77,62 & En yüksek & $-9,88$ \\
Ortanca değer & 50,62 & Ortanca değer & $-16,75$ \\
Standart sapma & 9,24 & Standart sapma & 1,34 \\
Değişim Katsayısı & 18,29 & Değişim Katsayısı & $-8,09$ \\
Basıklık & 0,35 & Basılık & 4,43 \\
Çarpıklık & $-0,07$ & Çarpıklık & 1,52 \\
\hline
\end{tabular}

Ağustos 2012 tarihli Radarsat-2 uydu görüntüsünden elde edilen gerisaçılım değerleri ile toprak nem değerleri arasında pozitif yönde ve istatistiksel olarak önemli düzeyde ilişki belirlenmiştir $(r=0,506, p<0,05)$ (Şekil 12, Çizelge 6). Toprak neminin az olduğu ve bitki örtüsünün olmaması nedeniyle toprak nemi ve gerisaçılım değerleri arasında ilişki diğer aylara göre daha iyi sonuç vermiştir. Wang ve ark. (2003), ERS-2 ve Landsat-TM uydu görüntüsü kullanarak, yarı kurak alanda yürüttükleri çalışmada, radarın gerisaçılım değerlerinin kuru toprak şartlarında pozitif, ancak toprak neminin yüksek olduğu zamanlarda negatif bir korelasyon olduğunu bildirmişlerdir. Bu çalışmada da 20 toprak neminin $(<10 \%)$ en az olduğu örnekleme döneminde nem ile radarın gerisaçılım değerleri arasındaki ilişki pozitif ve önemli bulunmuştur. Toprak neminin \%10'un altına düştüğünde radar görüntülerinden elde edilen gerisaçılım ile toprak nemi arasındaki ilişki daha belirgin hale gelmektedir. Özellikle kurak dönemlerde radar görüntüleri nem izlemede etkinliği artırmaktadır.

Aralık 2012 tarihli Radarsat-2 uydu görüntüsünden elde edilen gerisaçılım değerleri ile toprak nem değerleri arasında istatistiksel olarak önemli düzeyde ilişki belirlenmemiştir (Şekil 13, Çizelge 7). 
Cuizhen ve ark. (2004) ERS-2 radar görüntüsü ve Landsat TM uydu görüntülerini kullanarak yarı kurak alanlarda toprak nemi belirlemeye çalışmışlardır. Hem radar hem de optik görüntüleri bir arada kullanarak analitik ve sayısal görüntü birleştirme tekniklerinden görüntü birleştirmeyi (image fusion) kullanarak toprak nemi ile radar görüntüsü arasında daha iyi bir ilişki bulduklarını bildirmişlerdir. $\mathrm{Bu}$ çalışma kapsamında elde edilen tüm veriler ışığında, radar görüntülerinin tek başına toprak nem izleme çalışmalarında kullanılması yerine, eş zamanlı olarak optik görüntüler ile izlenmesinin daha güvenilir sonuçlar verebileceğini ortaya koymuştur.

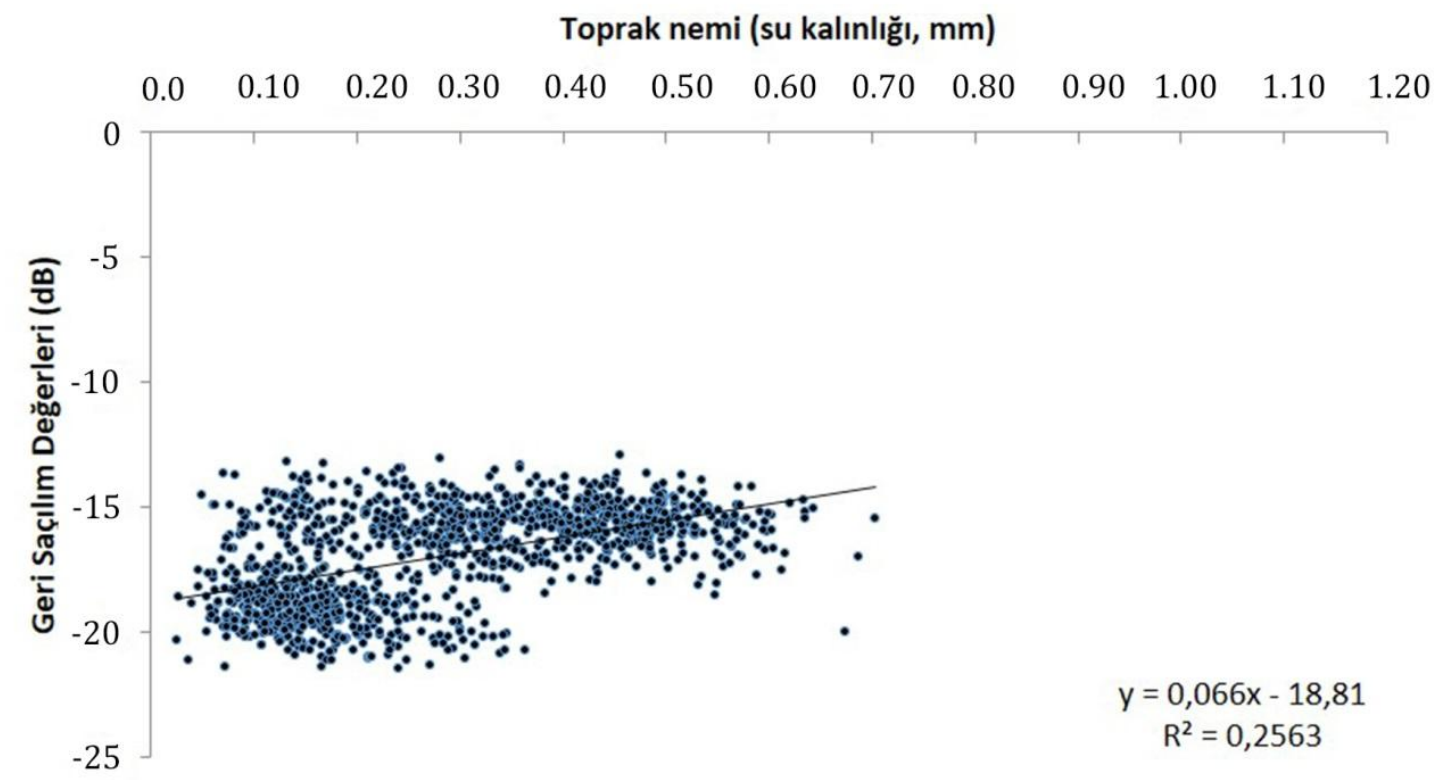

Şekil 12. Toprak nem değerleri ile Ağustos 2012 tarihli Radarsat-2 görüntüsü sigmanought verileri arasındaki istatistiksel ilişki

Figure 12. Statistical relationship between soil moisture and sigma nought data of Radarsat-2 image dated August 2012

Çizelge 6. Toprak nemi ile Ağustos 2012 tarihli Radarsat-2 görüntüsü sigmanought değerleri tanımlayıcı istatistik verileri

Table 6. Descriptive statistical data of soil moisture and sima nought values of Radarsat-2 image dated August 2012

\begin{tabular}{cccc}
\hline \multicolumn{2}{c}{ Toprak Nemi (mm, su kalınlık) } & \multicolumn{2}{c}{ Geri saçılım $(\mathrm{dB})$} \\
\hline Örnek sayısı & 1165 & Örnek sayısı & 1165 \\
Ortalama & 0,266 & Ortalama & $-16,92$ \\
En düşük & 0,026 & En düşük & $-21,44$ \\
En yüksek & 0,701 & En yüksek & $-12,94$ \\
Ortanca değer & 0,269 & Ortanca değer & $-16,41$ \\
& & & \\
Standart sapma & 14,78 & Standart sapma & 1,92 \\
Değişim KatsayıS1 & 51,92 & Değişim Katsayısı & $-11,39$ \\
Basıklık & $-0,93$ & Basılılı & $-1,01$ \\
Çarpıklık & 0,38 & Çarpıklık & $-0,35$ \\
\hline
\end{tabular}




\section{Toprak nemi (su kalınlığı, mm)}

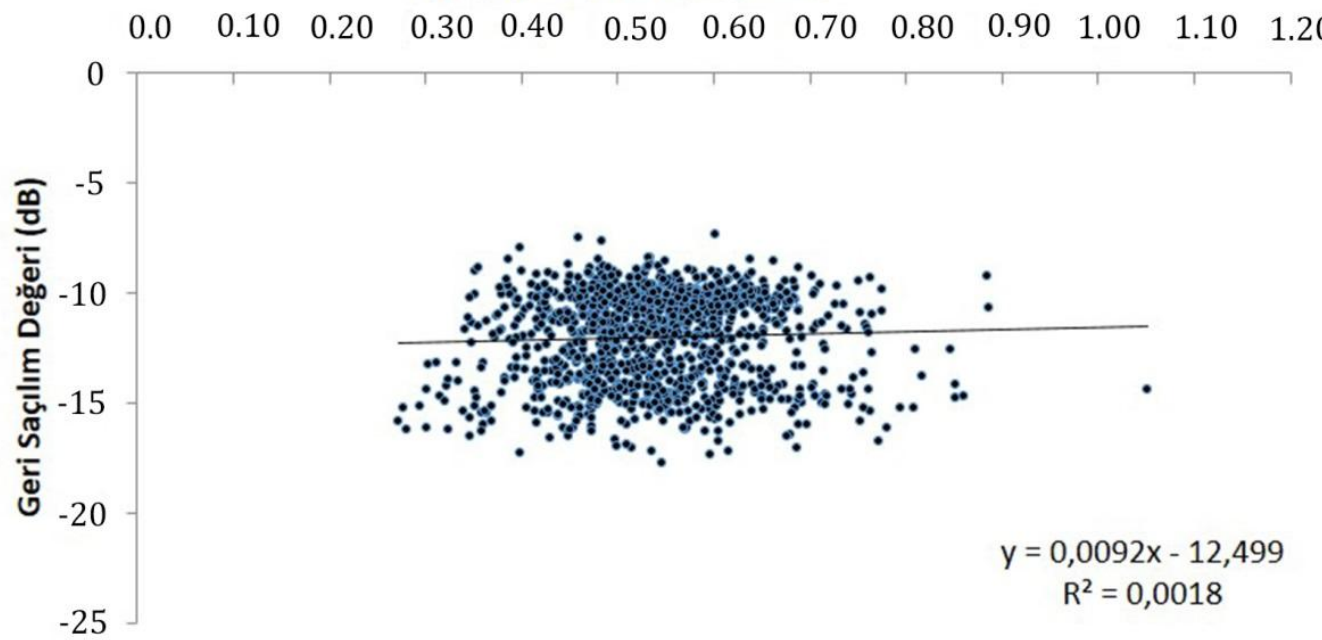

Şekil 13. Toprak nem değerleri ile Aralık 2012 tarihli Radarsat-2 görüntüsü sigmanought verileri arasındaki istatistiksel ilişki

Figure 13. Statistical relationship between soil moisture and sigmanought data of Radarsat-2 image dated December 2012

Çizelge 7. Toprak nemi ile Aralık 2012 tarihli Radarsat-2 görüntüsü sigmanought değerleri tanımlayıcı istatistikleri

Table 7. Descriptive statistical of soil moisture and sigmanought values of Radarsat-2 image dated December 2012

\begin{tabular}{cccc}
\hline \multicolumn{2}{c}{ Toprak Nemi (mm, su kalınlık) } & \multicolumn{2}{c}{ Geri saçılım $(\mathrm{dB})$} \\
\hline Örnek sayısı & 1165 & Örnek sayısı & 1165 \\
Ortalama & 0,539 & Ortalama & $-12,00$ \\
En düşük & 0,272 & En düşük & $-17,76$ \\
En yüksek & 1,052 & En yüksek & $-7,33$ \\
Ortanca değer & 0,534 & Ortanca değer & $-11,46$ \\
Standart sapma & 9,45 & Standart sapma & 2,07 \\
Değişim Katsayısı & 17,53 & Değişim Katsayısı & $-17,26$ \\
Basıklık & 1,09 & Basılık & $-0,87$ \\
Çarpıklık & 0,40 & Çarpıklık & $-0,45$ \\
\hline
\end{tabular}

\section{Sonuc}

Toprak neminin zamansal ve mekânsal değişimi, özellikle toprağın bulunduğu topoğrafik koşullar (eğim ve eğimin şekli; konkav-iç bükey, konveks-dış bükey veya linear-doğrusal ve bunların kombinasyonlarından oluşan eğim bileşenleri), iç drenaj, üzerindeki bitki örtüsü, toprak derinliği, tekstür, kil tipi, mineralojik bileşim, kimyasal bileşim, tekstür, geçirgenlik gibi özelliklere ve insanların arazi kullanımlarındaki farklılıklara göre ortaya çıkar. Bu özellikler arasında, özellikle toprak kalınlığı (etkili toprak derinliği) toprakta suyun depolanması açısından, büyük önem arz etmektedir.
Altınova Tarım İşletmesi arazisinde yürütülen bu çalışmada, yarı kurak iklim bölgelerinde toprak nem izleme çalışmalarında Radarsat-2 verilerinin kullanılabilirliği incelenmiştir. Bu amaçla 2011 Aralık, 2012 Nisan, Ağustos ve Aralık olmak üzere 4 farklı tarihli Radarsat-2 uydu görüntüsü kullanılmıştır. Uydu görüntüsü ile eş zamanlı olarak deneme alanı içerisinde toprak nem örneklemesi yapılmıştır. Çalışmada $250 \mathrm{~m}$ aralıkla yapılan toprak nem örnekleme sonuçlarının Radarsat-2 verileri ile ilişkilendirilmesinde en iyi sonuçların toprakların en az nem düzeyine sahip olduğu Ağustos verilerde görülmüştür. Diğer bir deyişle, radar görüntülerinde renk tonu bilgisi (gri skala) ortamdaki hedef nesnelerin pürüzlülüğü, yüksekliği, dalga boyu, geliş açısı ve polarizasyon gibi parametrelere bağlıdır. Radar görüntüsü ile toprak nemi çalışması yürütülürken 
C bant ve düşük açılı görüntülerin alınmasının daha faydalı olacağı düşünülmektedir. Radar görüntülerinde geri saçılımın az olması koyu renkli yani gri skalanın yaklaşık siyah aralığında görüntü oluşmasına neden olurken, yüksek gerisaçılımlar açık tonlu, yani gri skalanın beyaza yakın aralığında görüntü oluşturur. $\mathrm{Bu}$ nedenle radar verileri ile benzer çalışmaların yürütülmesinde diğer optik görüntüler (Landsat multispectral vs.) ile çalışmanın desteklenmesi büyük önem arz etmektedir. Ek olarak, işletmede yapılan toprak nem izleme çalışmalarının "Su Yilı" başlangıcında Ekim ayında başlatılması ve nadas sistemi nedeniyle en az iki y1l boyunca izlenmesi, hatta toprak nem izleme çalışmasının ürün hasadının yapılmasından sonra hemen başlatılarak 30 ay kadar süreyle yürütülmesi, ekim deseni, toprak özelliklerinin dikkate alınarak, nadas bozma, birleme, ikileme, üçleme gibi tüm faktörler dikkate alınarak, değerlendirilmesinin daha iyi sonuçlar verebileceğini göstermiştir.

Araştırma sonuçları radar görüntülerinin tek başına toprak nem değişiminin izlenmesi çalışmalarında kullanılmasının riskler taşıyabileceği, radar verilerinin diğer verilerle (optik görüntü) beraber kullanılmasının yararlı olabileceği (eş zamanlı uydu görüntüleri ile image fusion) düşünülmektedir. Günümüzde farklı çalışma prensipleri ve özelliklerinden dolayı, Radar veya SAR uydu verileri havza bazında yapılan hidrolojik döngülerin tanımlanmasında, toprak suyunun izlenmesinde, bitki örtüsü değişimlerinin izlenmesinde, ürün rekolte tahminlerinde ve bitki su tüketim çalışmalarında başarılı olarak kullanılmaktadır. Bu nedenlerle bu araştırma çerçevesinde, Radar/SAR verileriyle toprak nem değişimlerinin zamansal ve konumsal olarak izlenerek, bu değișimlerin toprak özellikleri (toprak serisi haritalama sınıları) ile ilişkilerinin belirlenmesinde kullanılabilirliği önem arz etmektedir. Ayrıca radar görüntülerinden elde edilen gerisaçılım değerleri arasında toprak nemine etki eden toprak parametreleri arasındaki ilişkilerin incelenmesi yararlı olacaktır.

\section{Teșekkür}

$\mathrm{Bu}$ çalışmada TÜBITTAK tarafından desteklenen 1100729 nolu proje kapsaminda elde edilen veriler kullanılmıştır. TÜBİTAK'a ve proje ekibine katkılarından dolayı teşekkür ederim

\section{Kaynaklar}

Alexander, L., Ralf L., Wolfram, M., 2006. Deviation of surface soil moisture from ENNVISAT ASAR wide swath and image mode Data in agricultural area, IEEE Trans. Geosci. Remote Sensing, 44 (4): 889 99.

Alvarez-Mazos, J., Casali, J., Gonzalez-Audicana, M., Verhoest, N. E. C., 2005. "Correlation between ground measured soil moisture and RADARSAT-1 derived backscattering coefficient over an agricultural catchments of Navvare (North of Spain). Biosystems Engineering 92: 119-133.

Anonim, 2019. http://www.tigem.gov.tr/.

Baghdadi, N., King, C., Chanzy, A., Wigneron, J. P., 2002. An empirical calibration of the integral equation model based on SAR Data, soil moisture and surface roughness measured over bare soils. International Journal of Remote Sensing 23: 43254340.

Baghdadi, N., Holah, N., Zribi, M., 2006. Soil moisture estimation using multi-incident and multipolarization ASAR data. Int. J. Remote Sens., 27 (10): 1907-20.

Bayramin, İ., Kılıç, Ş., Dengiz, O., Başkan, O., Tunçay, T., Yıldırım, A., Koç, A., Öğütmen, Ç., 2013. Radar görüntülerinin toprak etüt ve haritalama çalışmalarında kullanımı. TUBİTAK TOVAG 110 O 729 nolu TOVAG Projesi Sonuç Raporu.

Beaudoin, A., Le Toan, T., Gwyn, Q. H. J., 1990. SAR observations and modeling of the C-Band backscatter variability due to the multiscale geometry and soil moisture. IEEE Transactions on Geoscience and Remote Sensing 28: 886-895.

Boisvert, J. B., Gwyn, Q.H., Chanzy, A., Major, D. J., Brisco, B., Brown, R. J., 1997. Effects of soil moisture gradients on modeling radar backscattering from bare soils. International Journal of Remote Sensing 18: 153-170.

Chen, J. S., Lin, H., Pei, Z. Y., 2007. Application of ENVISAT ASAR data in mapping rice crop growth in Southern China. IEEE Trans. Geosci. Remote Sens., 4 (3): 431-35.

Cuizhen, W., Qi, J., Moran, S., Robin, M., 2004. Soil moisture estimation in a semiarid rangeland using ERS-2 and TM imagery. Remote Sensing of Environment 90: 178-189.

De Lannoy, G.J.M., Verhoest, N.E.C., Houser, P.R., Gish, T.J., van Meirvenne, M., 2006. Spatial and temporal characteristics of soil moisture in an intensively monitored agricultural field (OPE3). Journal of Hydrology 331, 719-730.

Dubois, P. C., Zyl, J. V., Engman, E. T., 1995. Measuring soil moisture with imaging radars. IEEE Transactions on Geoscience and Remote Sensing 33: 915-926.

Dobson, M. C., Ulaby, F. T., 1986. Preliminary evaluation of the SIR-B response to soil moisture, surface roughness, and crop canopy cover. IEEE Transaction on Geoscience and Remote Sensing 24: 517-526.

Eliason, E.M., McEwen, A.S., 1990. Adaptive box filters for removal of random noise from digital images. Photogrammetric Engineering \& Remote Sensing, vol. 56, no. 4: 453, 1990.

Esetlili, M. T., 2008. Sentetik açıklıklı radar (mikrodalga) uydu görüntüleri kullanılarak toprak 
özelliklerinin belirlenebilirliği üzerine bir araştırma. Ege Üniversitesi Fen Bilimleri Enstitüsü Doktora Tezi.

Fung, A. K., Chen, K. S., 1992. Backscattering from a randomly rough dielectric surface. IEEE Trans. on Geosci. and Remote Sensing, 30(2): 356-69.

Gish, T.J., Walthall, C.L., Daughtry, C.S.T., Kung, K.J.S., 2005. Using soil moisture and spatial yield patterns to identify subsurface flow pathways. Journal of Environmental Quality 34: 274-286.

Gish, T.J., Prueger, J.H., Daughtry, C.S.T., Kustas, W.P., McKee, L.G., Russ, A.L., Hatfield, J.L., 2011. Comparison of field-scale herbicide runoff and volatilization losses: an eight-year field investigation. Journal of Environmental Quality 40, 1432-1442.

Hegarat-mascle, S.L., Zribi, M., Alem, F., Weisse, A., Loumagne, C., 2000. Soil moisture estimation from ERS/SAR data: toward an operational methodology. Remote Sensing Environmental, 72: 290 - 303.

Huangg, Y. and Genderen, J.L., 1996. Evaluation of several filtering techniques for ERS-1\&2 Imagery. International Archives of Photogrammetry and Remote Sensing Vol. XXXI Part B2. Vienna 1996.

Holah, N., Baghdadı, N., Zribi, M., Brund, A., King, C., 2005. Potential of ASAR/ENVISAT for the characterization of soil surface parameters over bare agricultural fields. Remote Sens. Environ, 96 (1): 78-86.

Jackson, T., Schmugge, J., Engman, E., 1996. Remote sensing applications to hydrology: soil moisture. Hydrol. Sci. J. 41: 517-530.

Kelly, R.E.J., Davie, T.J.A., Atkinson, P. M., 2003. Explaining temporal and spatial variation in soil moisture in a bare field using SAR imagery. International Journal of Remote Sensing 24, 30593074.

Kutilek, M., Nielsen, D.R., 1994. Soil hydrology. Catena Verlag: Cremlingen-Destedt, Germany.

$\mathrm{Li}, \mathrm{Z}$., 2004. Soil moisture measurement and retrieval using Envisat ASAR imagery. In: IEEE Geoscience Remote Sensing Proceedings, 5 (20-24),pp: 353942.

Lin, H.S., Kogelmann, W., Walker C, Bruns, M.A., 2006a. Soil moisture patterns in a forested catchment: a hydropedological perspective. Geoderma 131, 345-368.

Lin, H.S., Bouma, J., Pachepsky, Y., Western, A.W., Thompson, J.A., van Genuchten, M.T., Vogel, H., Lilly, A., 2006b. Hydropedology: synergistic integration of pedology and hydrology. Water Resources Research 42, W05301.

Lin, H.S., Zhou, X.B., 2008. Evidence of subsurface preferential flow using soil hydrologic monitoring in the Shale Hills catchment. European Journal of Soil Science 59, 34-49.

Löw, H., Ludwig, R., Mauser, W., 2005. Use of microwave remote sensing data to montor spatio temporal characteristics of surface soil moisture at local and regional scales. Advanges in Geosicences $5,49-56$.

McNaim, H., Merzouki, A., Pacheco, A., 2010. Estimating surface soil moisture using RADARSAT-2. International Archives of the Photogrammetry, Remote Sensing and Spatial Information Science, Volume XXXVIII, Part 8, Kyoto Japan.

Moran, M.S., Hymer, D.c., Qi, J., Sano, E.E., 2000. Soil moisture evaluation using multi-temporal synthetic aperture radar (SAR)in semiarid rangeland. Agricultural and Forest Meteorology (105): 69-90.

Narayanan, R. M., Hirsave, P. P., 2001. Soil Moisture estimation models using SIR-C SAR data: a case study in New Hampshire, USA. Remote Sensing of Environment 75, 385-396.

Oldak, A., Jackson, T.J., Starks, P., Elliott, R., 2003. Mapping near surface soil moisture on regional scale using ERS-2 SAR data. International Journal of Remote Sensing 24: 579-4598.

Paloscia, S., Pettinato, S., 2008. A Comparison of algorithms for retrieving soil moisture from ENVISAT/SAR images. IEEE Trans. on Geoscience and Remote Sensing, vol. 46, No. 10.

Sano, I. I., Huete, A. R., Troufleau, D., Moran, M. S., Vidal, A., 1998. Relation between ERS-1 synthetic aperture radar data and measurements of surface roughness and moisture content of rocky soils in semiarid rangeland. Water Resources Researches 34: 1491-1498.

Shakil, A. Romshoo, T. O., Katumi, M., 2000. A Multipolarized and multi- angle C- band radar system for soil mositure determination under bare soil condition. Asian Association on Remote Sensing, Proceeding ACRS, Section:14, SAR/InSAR.

Shao, Y., Hu, Q., Hu, H., Guo, Y., Lu, Q., Dong, Chunming Han., 2003. Effect of dielectric properties of moist salinized soils on backscattering coefficients extracted from RADARSAT image. IEEE Transactions on Geoscience and Remote Sensing, No: 41: 1879-1888.

Siegert, F., Ruecker, G., 2000. Use of multitemporal ERS-2 SAR images for identification of burned scars in South-East Asian tropical forest. International Journal of Remote Sensing 21: 831837.

Soil Survey Staff., 2015. Illustrated guide to Soil Taxonomy. Version 1.1. U.S. Department of Agriculture. National Resources Conservation Service, Lincoln, Nebraska.

Trangmar, B.B., Yost, R.J., Uehara, G., 1985. Application of geostatistics to spatial studies of soil properties. Advance in Agronomy, 38, 65-91.

Trangmar, B.B., Yost, R.J., Wade, M.K., Uehara, G. and Sudjadi, M., 1987. Spatial variation of soil properties and rice yield on recently cleared land. Soil Sci. Soc. Am. J., 51, 668-674. 
Verhoest, N. E. C., Troch, P. A., Paniconi, C., De Troch, F. P., 1998. Mapping basin scale variable sources areas from multi-temporal remotely sensed observations of soil moisture behaviour. Water Resources Research, 34 (12), 3235-3244.

Walker, J.P., Houser, P.R., Willgoose, G.R., 2004. Active microwave remote sensing for soil moisture measurement: a field evaluation using ERS-2. Hydrol. Process., 18: 1975-1997.

Wang, C., Qi, J., Moran, S., Marsett, R., 2003. Soil moisture estimation in a semiarid rangeland using ERS-2 and TM imagery. Remote Sensing of Environment 90: 178-189.

Wang, C., Qi, J., Moran, S., Marsett, R., 2004. Soil moisture estimation in a semiarid rangeland using ERS-2 and TM imagery. Remote Sensing of Environment 90: 178-189.

Western, A.W., Grayson, R.B., Blöschl, G., Willgoose, G.R., McMahon, T.A., 1999. Observed spatial organization of soil moisture and its relation to terrain indices. Water Resources Research 35, 797810
Western, A.W., Zhou, S.L., Grayson, R.B., McMahon, T.A., Blöschl, G., Wilson, D.J., 2004. Spatial correlation of soil moisture in small catchments and its relationship to dominant spatial hydrological processes. Journal of Hydrology 286, 113-134.

Wilding, L. P., 1985. Spatial variability: It's documentation, accommodation and implication to soil surveys: In: Soil Spatial Variability. (Eds: Nielsen, D.R and J. Bournaj Pudoc, pp. 166-194, Wageningen, The Netherlands.

Zribi, M., O. N., Holah N., Fafin, O., Guerin, C. 2005 a. Evaluation of rough surface soil description with ASAR-ENVISAT radar data. Remote Sensing of Environment 95: 67-76.

Zribi, M., Baghdadi, N., Holah, N., Fafin, O., 2005 b. New methodology for soil surface moisture estimation and its application to ENVISAT-ASAR Multiincidence data inversion. Remote Sensing of Environment 96: 485-496. 